\title{
Environmental Occurrence, Toxicity Concerns, and Degradation of Diazinon Using a Microbial System
}

\section{OPEN ACCESS}

Edited by:

Paulo Costa Lemos, NOVA School of Science and Technology, Portugal

Reviewed by:

Waqas Wakil,

University of Agriculture Faisalabad,

Pakistan

Anita Sharma,

Govind Ballabh Pant University of Agriculture and Technology, India

${ }^{*}$ Correspondence:

Shaohua Chen

shchen@scau.edu.cn

Specialty section:

This article was submitted to

Microbiotechnology,

a section of the journal

Frontiers in Microbiology

Received: 01 June 2021

Accepted: 08 October 2021

Published: 01 November 2021

Citation:

Wu X, Li J, Zhou Z, Lin Z, Pang S,

Bhatt P, Mishra $S$ and Chen $S$ (2021)

Environmental Occurrence, Toxicity

Concerns, and Degradation

of Diazinon Using a Microbial System.

Front. Microbiol. 12:717286.

doi: 10.3389/fmicb.2021.717286

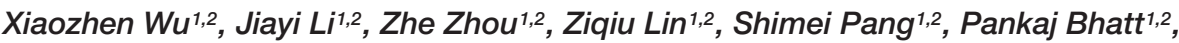 Sandhya Mishra ${ }^{1,2}$ and Shaohua Chen ${ }^{1,2 *}$}

\footnotetext{
1 State Key Laboratory for Conservation and Utilization of Subtropical Agro-bioresources, Guangdong Province Key Laboratory of Microbial Signals and Disease Control, Integrative Microbiology Research Centre, South China Agricultural University, Guangzhou, China, ${ }^{2}$ Guangdong Laboratory for Lingnan Modern Agriculture, Guangzhou, China
}

Diazinon is an organophosphorus pesticide widely used to control cabbage insects, cotton aphids and underground pests. The continuous application of diazinon in agricultural activities has caused both ecological risk and biological hazards in the environment. Diazinon can be degraded via physical and chemical methods such as photocatalysis, adsorption and advanced oxidation. The microbial degradation of diazinon is found to be more effective than physicochemical methods for its complete clean-up from contaminated soil and water environments. The microbial strains belonging to Ochrobactrum sp., Stenotrophomonas sp., Lactobacillus brevis, Serratia marcescens, Aspergillus niger, Rhodotorula glutinis, and Rhodotorula rubra were found to be very promising for the ecofriendly removal of diazinon. The degradation pathways of diazinon and the fate of several metabolites were investigated. In addition, a variety of diazinon-degrading enzymes, such as hydrolase, acid phosphatase, laccase, cytochrome $\mathrm{P} 450$, and flavin monooxygenase were also discovered to play a crucial role in the biodegradation of diazinon. However, many unanswered questions still exist regarding the environmental fate and degradation mechanisms of this pesticide. The catalytic mechanisms responsible for enzymatic degradation remain unexplained, and ecotechnological techniques need to be applied to gain a comprehensive understanding of these issues. Hence, this review article provides in-depth information about the impact and toxicity of diazinon in living systems and discusses the developed ecotechnological remedial methods used for the effective biodegradation of diazinon in a contaminated environment.

Keywords: diazinon, toxicity, abiotic degradation, microbial degradation, degradation pathways, catalytic mechanisms

\section{INTRODUCTION}

With the rapid development of agriculture, organophosphorus pesticides (OPs) are characterized by specificity, broad spectrum applicability, and high efficiency. They play a prominent role in the control of agricultural pests and diseases. Since 1960, OPs have occupied the highest market share of pesticides (19\% of the world market) (Villiot et al., 2018). Diazinon (O,Odiethyl-O-[6-methyl-2-(1-methyl-ethyl)-4-pyrimidine] thiophosphate) is a broad-spectrum, highly effective, medium-low toxicity organophosphate insecticide. It is one of the most commonly 
detected OPs in groundwater, drinking water and surface water, which is an especially serious problem (Cao et al., 2018; Glinski et al., 2018). Environmental residues of diazinon can cause harm to nontarget organisms through the air, water, soil, and food chain (Figure 1).

During the application process, only $10 \%$ of the pesticides used can reach the target organisms, and the remaining $90 \%$ is distributed in the environment. High concentrations of diazinon can be easily detected in the rivers of the United States, Italy, Spain, China and other countries (Hajirezaee et al., 2017; Al-Otaibi et al., 2019; Mena et al., 2020). Diazinon has a thiophosphate backbone, which is metabolized by cytochrome P450 to form the OP-oxon form, which inhibits acetylcholinesterase (AChE), causes nerve tissue failure and kills insects. After accidental exposure to diazinon, fish, shrimp, shellfish and human children can develop neurological and developmental disorders, so they are restricted by the U.S. Environmental Protection Agency (Yen et al., 2011; Montuori et al., 2016; Sharma et al., 2019). Clearly, there is an urgent need to remove residual diazinon from the environment.

A high number of researchers have performed research studies around this topic, and the previously established degradation methods can be divided into abiotic degradation and microbial degradation (Kumar et al., 2018; Mulla et al., 2018; Baharum et al., 2020; Sikakwe et al., 2020). Diazinon can be further degraded through continuous optimization of physical and chemical conditions. Previous studies showed that copperdoped $\mathrm{ZnO}$ nanorods could overcome the disadvantages of $\mathrm{ZnO}$ nanoparticles as nanocatalysts and could perform photocatalytic degradation of organophosphorus pesticides, such as diazinon, with a degradation efficiency of $96.97 \%$, which was more valuable than the UV/ZnO process (Shirzad-Siboni et al., 2017). Alalm et al. (2015) used a combination technique. In the first stage, a solar heterogeneous $\mathrm{TiO}_{2}$ photocatalyst was used, powdered activated carbon (PAC) was selected for adsorption, and nearly $100 \%$ of diazinon was removed. Further study found that there are three main byproducts, namely, diazoxon 7methyl-3-octyne, 2-isopropyl-6-methyl-4pyrimidinol and diethyl phosphonate (Toolabi et al., 2018). However, abiotic degradation still has some disadvantages, such as incomplete degradation, high production cost, and complex operation (Arora, 2020; Saleh et al., 2020). Thus, it is very important to develop cleaner, cheaper and easier removal technologies.

Microbial degradation of pesticides has the characteristics of high efficiency, low cost, environmental protection, and sustainability, which has attracted the attention of researchers (Mishra et al., 2020; Li et al., 2021; Lin et al., 2021). Many previous studies have shown that biodegradation of diazinon is a promising approach for the remediation of diazinoncontaminated environments. These microorganisms include Stenotrophomonas, Bacillus serrata, Burkholderia, Streptomyces, and Aspergillus niger, which are highly effective in the removal of diazinon when provided appropriate growth conditions (Cycoń et al., 2009; Góngora-Echeverría et al., 2020; Hamad, 2020). The reason why these microorganisms can effectively degrade diazinon lies in the various enzymes contained in their bodies. These enzymes have high enzyme activity and a variety of hydrolysis and oxidation functions, which can turn the pollutants into short chain products with low toxicity. However, the $\mathrm{pH}$, temperature, and low stability properties of these enzymes limit their use in industrial applications (Bhatt et al., 2020b; Mishra et al., 2021). At present, people use the immobilization technology of enzymes to improve the thermal stability, reduce the inhibition of the product, and overcome the common difficulty of solubility. However, researchers do not have the complete system needed to define the effective degrading enzymes contained in microorganisms. This increases the difficulty of subsequent studies on the degradation of diazinon. A review of relatively complete and clear degradation pathways and construction of related degradation enzymes is of great reference value.

This article will discuss both the role in and toxicity of diazinon in life systems and explain the application of microbial strains to the degradation of diazinon. In addition, the mechanisms and kinetics of local microbial strains were compared, and they were found to be effective for the degradation of diazinon. We will focus on the degradation pathways and catalytic mechanisms of diazinon to better understand how microorganisms can enhance the degradation of diazinon, thereby working towards rectifying its dispersion in the natural environment.

\section{TOXICITY OF DIAZINON}

Diazinon is widely used in the control of various insects and can be used as an insecticide in agricultural production systems. The related properties of diazinon are shown in Table 1. In the field of veterinary medicine (Mitra and Maitra, 2018), diazinon is often used as an acaricide and as an insect repellent sprayed on livestock and poultry. At the same time, it was also categorized as a moderately hazardous pollutant of class II by the World Health Organization (Pirsaheb et al., 2014; Jonidi-Jafari et al., 2015). In the United States, the phasing-out of diazinon for indoor and outdoor use began in 2002. Diazinon is highly effective in pest control and is widely used in fruits, vegetables, nuts, and ornamental products, and up to 100 tons can be used per year (Shrestha et al., 2018). In Iran and other Middle Eastern countries, it is used in grape cultivation to good effect (Bakırc1 et al., 2014; Pirsaheb et al., 2017; Philippe et al., 2021). However, continuous use of diazinon causes it to accumulate in the environment and damage the health of nontarget organisms by entering the food chain.

Because of the trend towards large-scale usage of pesticides, the pollution sources of pesticides are not only limited to the intensive use of pesticides in urban areas but can also be linked to the chemical industry and farmland (Liu et al., 2015; Wee et al., 2016; Zainuddin et al., 2020). Pesticides and their residues (metabolites) can condense into rain through surface runoff, soil leaching and transpiration, be deposited on the surface or in tissues of plants, enter drinking water and groundwater, and eventually reach nontarget organisms, including humans (Palma et al., 2014; Chaza et al., 2018; Sumon et al., 2018; Villiot et al., 2018; Triassi et al., 2019). 


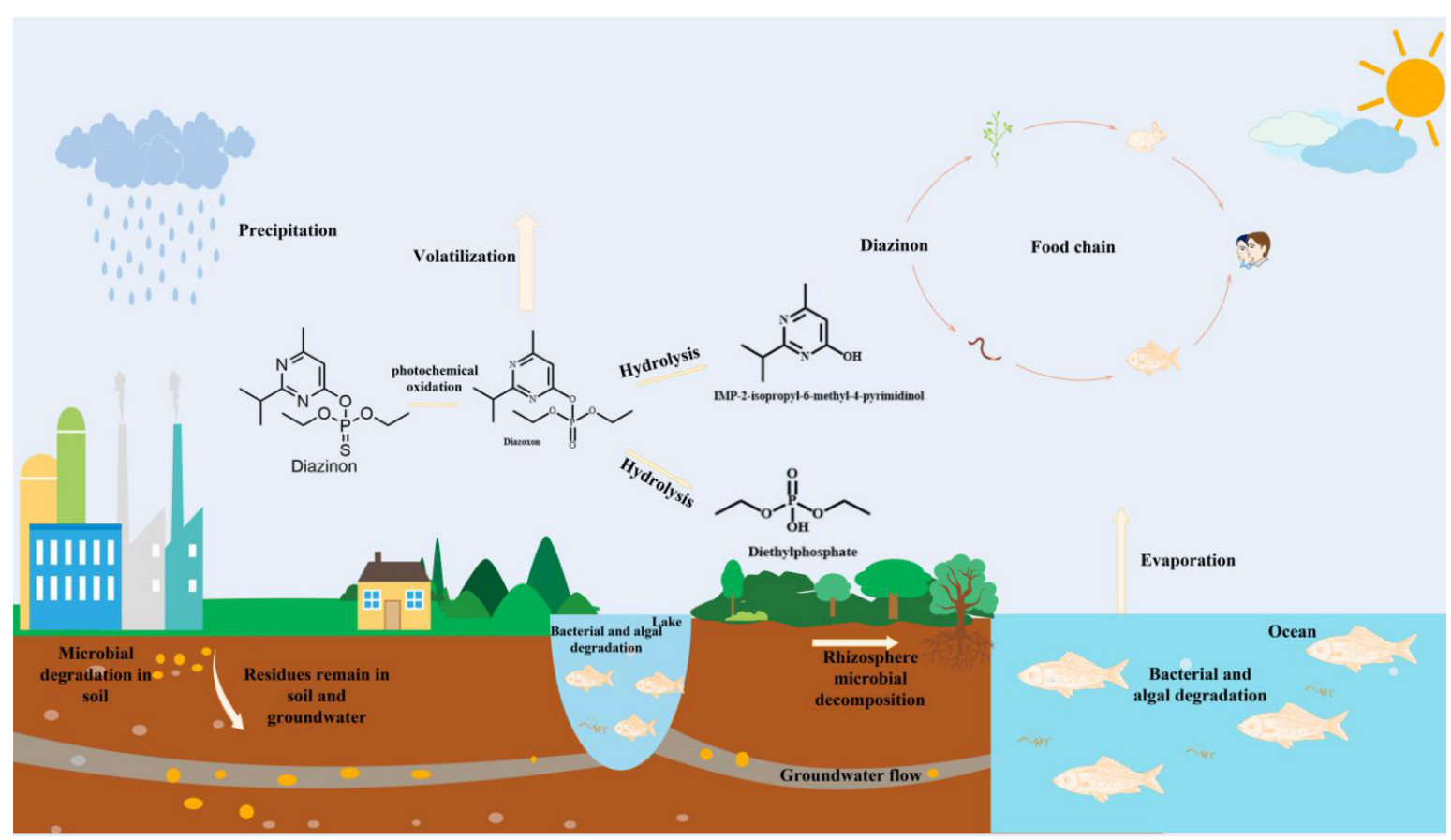

FIGURE 1| The fate and occurrence of diazinon in the environment.

The levels of diazinon in several water sources have been found to exceed the standard, and the treatment processes used in diazinon agrochemical plants and sewage treatment plants still cannot fully degrade pesticide residues (Fadaei et al., 2012; Arellano-Aguilar et al., 2017; Hamad, 2020). Coming into contact with diazinon triggers the phosphorylation of cholinesterase in vivo (Glavan et al., 2018; Díaz-Resendiz et al.,

TABLE 1 | Physical and chemical properties and structure of diazinon (Malakootian et al., 2020).

\begin{tabular}{ll}
\hline Description & Properties \\
\hline Molecular structure & \\
& O,O-Diethyl O-2-isopropyl- \\
IUPAC name & $6-$ methyl-4-pyrimidinyl \\
& phosphorothioate \\
Molecular formula & $\mathrm{C}_{12} \mathrm{H}_{21} \mathrm{~N}_{2} \mathrm{O}_{3} \mathrm{PS}$ \\
Molar mass (g/mol) & 304.3 \\
Density & $1.116-1.118\left(20^{\circ} \mathrm{C}\right)$ \\
Toxicity & $\mathrm{LD}_{50}(\mathrm{mg} / \mathrm{kg})$ \\
Octanol-water Partition & 3.81 \\
coefficient, logK & \\
Solubility in water & $40 \mathrm{mg} / \mathrm{L}$ at $25^{\circ} \mathrm{C}$ \\
Dissociation constant $(\mathrm{pKa})$ & 2.6
\end{tabular}

2019). Acetylcholinesterase is inactivated and toxic. A large number of pesticides in the environment continue to accumulate, not only inhibiting insect acetylcholinesterase activity but also interfering with the nervous system of various organisms, causing neurotoxicity (Hajirezaee et al., 2017; Glavan et al., 2018; Mena et al., 2020). Čolović et al. (2015) also found that diazinon metabolites were nontoxic, but their stimulation by superoxide dismutase was up to $30 \%$, and a high concentration of diazinon and its metabolites had a significant effect on lactate dehydrogenase activity.

Diazinon is also very harmful to aquatic organisms, especially local shellfish species in aquatic ecosystems (such as Digueti and Daphnia); under the stress of diazinon, its potential acute toxicity gradually reached a very high level (Arias-Andrés et al., 2018; Chen et al., 2018). In addition, $4.5 \mathrm{mg} / \mathrm{L}$ diazinon inhibited acetylcholinesterase in amphibian embryos, leading to endothelial cell changes and body length shortening and eventually leading to biological deformities (Aronzon et al., 2014). Velki et al. (2017) used an in vivo model of zebrafish to evaluate the effects of the commonly used insecticide diazinon on the early life stages of zebrafish, and the results showed that diazinon had influence on enzyme reactions and gene expression changes. Toledo-Ibarra et al. (2016) evaluated lipid and protein oxidative damage in Nile tilapia exposed to diazinon and found that proteins in the gills and liver tissues were more easily oxidized by diazinyl than lipids. In a recent study, Hajirezaee et al. (2017) reported, for the first time, the adverse effects of the exposure of Persian sturgeon larvae to diazinon on their seawater adaptation. Intestinal microorganisms in mice decompose organophosphates, including diazinon, into 
gluconeogenic substrates, which interfere with the normal activities of intestinal microorganisms, leading to glucose regeneration and glucose intolerance, thereby increasing the incidence of diabetes (Gao et al., 2017; Velmurugan et al., 2017).

Pesticides can affect host health in many ways, such as altering the composition of gut microbes and their metabolites. The introduction of diazinon into mice significantly reduced the bacterial population of the Lachnospiraceae family, which is involved in the production of short-chain fatty acids, caused bile acid disorder (Gao et al., 2017; Adamovsky et al., 2018), and destroyed intestinal mucosa and intestinal cells (Groh, 2017; Gillois et al., 2018). With the destruction of the intestinal flora balance and the enhancement of intestinal permeability, more lipopolysaccharides (LPS) are introduced into the body, ultimately triggering low-level inflammation (Ghetti, 2018; Liang et al., 2019). Large amounts of organophosphorus pesticides can inhibit acetylcholinesterase (AChE) in the central and peripheral nervous systems and promote an increase in acetylcholine, which can lead to nausea, headache, psychosis, depression, memory loss, chronic fatigue syndrome, and respiratory problems (Sultatos, 2006).

This series of environmental questions has constantly perplexed modern human beings. Finding a treatment technology with low price, complete degradation, and no secondary pollution through sustainable development is particularly important.

\section{ABIOTIC DEGRADATION OF DIAZINON}

\section{Physical and Chemical Degradation of Diazinon}

With increasing interest in diazinon, many studies have been carried out regarding its degradation. Physicochemical degradation is one of the most widely used methods, including photocatalyst treatment, advanced oxidation treatment, biological treatment membrane filtration, and ion exchange treatment (Hassan et al., 2017; Kumar et al., 2018; Pordel et al., 2019). The physical and chemical degradation methods of diazinon are shown in Table 2. Physical adsorption and chemical degradation are the main techniques used for pesticide degradation. A variety of adsorbents have been developed and used, and the optimization conditions of photocatalysts have also been archived. It has been proven that these methods are effective, but the use cost is relatively high (Jonidi-Jafari et al., 2015). In this type of experiment using $\mathrm{TiO}_{2}, \mathrm{TiO}_{2}$ particles cannot be separated from a solution after treatment (Baharum et al., 2020). The cost of the UV/ZnO photocatalysis process is high, and the links to serious environmental problems include the environmental hazards of mercury vapor lamps, including the high toxicity of mercury and the short lifespan of the lamps themselves (Hossaini et al., 2017). Considering the solubility and persistence of diazinon, an appropriate technology can be used to remove diazinon from water systems.

Considering the high content of diazinon in water, there are many methods to improve the removal rate of diazinon by optimizing the characteristics of adsorbents. The vast majority
TABLE 2 | Physical and chemical methods for diazinon degradation.

\begin{tabular}{|c|c|c|c|}
\hline $\begin{array}{l}\text { Processing } \\
\text { methods }\end{array}$ & $\begin{array}{l}\text { Reaction } \\
\text { conditions }\end{array}$ & Comments & References \\
\hline $\begin{array}{l}\mathrm{Fe}-\mathrm{TiO}_{2} / \text { Bent- } \\
\mathrm{Fe} \\
\text { photocatalysis }\end{array}$ & $\begin{array}{c}0.5 \mathrm{~g} / \mathrm{L} \text { of catalyst } \\
\text { Visible light ( } 36-\mathrm{W} \\
\text { compact bulb) } \\
\mathrm{pH}=5.6\end{array}$ & $\begin{array}{c}\text { 58.3\% of diazinon } \\
(25 \mathrm{mg} / \mathrm{L}) \text { was } \\
\text { degraded within } 6 \mathrm{~h}\end{array}$ & Phuong et al., 2019 \\
\hline $\begin{array}{l}\mathrm{WO}_{3} \\
\text { photocatalysis }\end{array}$ & $\begin{array}{l}0.5 \mathrm{~g} / \mathrm{L} \text { of catalyst } \\
\text { UV light (125- W } \\
\text { medium-pressure } \\
\text { UVC lamp) } \mathrm{pH}=3\end{array}$ & $\begin{array}{l}\text { 99.88\% of diazinon } \\
(20 \mathrm{mg} / \mathrm{L}) \text { was } \\
\text { degraded within } 2 \mathrm{~h}\end{array}$ & $\begin{array}{c}\text { Mohagheghian } \\
\text { et al., } 2016\end{array}$ \\
\hline $\begin{array}{l}\mathrm{Fe}-\mathrm{TiO}_{2} \\
\text { photocatalysis }\end{array}$ & $\begin{array}{l}0.1 \mathrm{~g} / \mathrm{L} \text { of catalyst } \\
\text { UV light (125-W } \\
\text { medium-pressure } \\
\text { UVC lamp) } \mathrm{pH}=7\end{array}$ & $\begin{array}{c}\text { 98.53\% of diazinon } \\
(50 \mathrm{mg} / \mathrm{L}) \text { was } \\
\text { degraded within } 2 \mathrm{~h}\end{array}$ & $\begin{array}{l}\text { Dehghani et al., } \\
2019\end{array}$ \\
\hline $\begin{array}{l}\text { MgO } \\
\text { photocatalysis }\end{array}$ & $\begin{array}{c}0.1 \mathrm{~g} / \mathrm{L} \text { of catalyst } \\
\text { UV light (5 lamps) } \\
\mathrm{pH}=7\end{array}$ & $\begin{array}{l}\text { 99.46\% of diazinon } \\
(5 \mathrm{mg} / \mathrm{L}) \text { was } \\
\text { degraded within } 2 \mathrm{~h}\end{array}$ & $\begin{array}{l}\text { Ahmadifard et al., } \\
2019\end{array}$ \\
\hline $\begin{array}{l}\text { Iron doped } \\
\mathrm{TiO}_{2} \\
\text { photocatalysis }\end{array}$ & $\begin{array}{c}0.4 \mathrm{~g} / \mathrm{L} \text { of catalyst } \\
\text { UV light (15-W low } \\
\text { pressure UV lamp) } \\
\text { pH }=5.5\end{array}$ & $\begin{array}{c}76 \% \text { of diazinon } \\
(30 \mathrm{mg} / \mathrm{L}) \text { was } \\
\text { degraded within } \\
100 \mathrm{~min}\end{array}$ & $\begin{array}{l}\text { Tabasideh et al., } \\
2017\end{array}$ \\
\hline $\begin{array}{l}\text { Cu-doped } \mathrm{ZnO} \\
\text { nanorods }\end{array}$ & $\begin{array}{c}0.2 \mathrm{~g} / \mathrm{L} \text { of catalyst } \\
\text { Gasoxygen } \\
\text { gas }=2 \mathrm{~L} / \mathrm{min} \\
\mathrm{pH}=7\end{array}$ & $\begin{array}{c}\text { 96.97\% of diazinon } \\
(50 \mathrm{mg} / \mathrm{L}) \text { was } \\
\text { degraded within } 2 \mathrm{~h}\end{array}$ & $\begin{array}{l}\text { Shirzad-Siboni } \\
\text { et al., } 2017\end{array}$ \\
\hline $\begin{array}{l}\mathrm{WO}_{3} \\
\text { nanostructures }\end{array}$ & $\begin{array}{c}\mathrm{WO}_{3} \\
\text { nanostructures: } \\
\text { sulfuric acid } \\
\left(\mathrm{H}_{2} \mathrm{SO}_{4}\right) 1.5 \mathrm{M}, \\
\text { nitric acid }\left(\mathrm{HNO}_{3}\right) \\
1.5 \mathrm{M}, \\
\text { methanesulfonic } \\
\text { acid }\left(\mathrm{CH}_{4} \mathrm{O}_{3} \mathrm{~S}\right) \\
1.5 \mathrm{M} \text { UV light } \\
\text { (500W xenon lamp) }\end{array}$ & $\begin{array}{l}\text { 90\% of diazinon } \\
(20 \mathrm{mg} / \mathrm{L}) \text { was } \\
\text { degraded within } \\
24 \mathrm{~h}\end{array}$ & $\begin{array}{l}\text { Roselló-Márquez } \\
\text { et al., } 2021\end{array}$ \\
\hline $\begin{array}{l}\mathrm{WO}_{3} \text {-doped } \\
\mathrm{ZnO} \\
\text { photocatalysis }\end{array}$ & $\begin{array}{c}10 \mathrm{mg} / \mathrm{cm}^{2} \text { of } \\
\text { catalyst UV light } \\
\text { (6-W low pressure } \\
\text { lamp) } \mathrm{pH}=7\end{array}$ & $\begin{array}{c}\text { 89\% of diazinon } \\
(20 \mathrm{mg} / \mathrm{L}) \text { was } \\
\text { degraded within } 2 \mathrm{~h}\end{array}$ & Maleki et al., 2020 \\
\hline $\begin{array}{l}\mathrm{WO}_{3} \text {-doped } \\
\mathrm{ZnO} \\
\text { photocatalysis }\end{array}$ & $\begin{array}{c}10 \mathrm{mg} / \mathrm{cm}^{2} \text { of } \\
\text { catalyst Sunlight } \\
\mathrm{pH}=7\end{array}$ & $\begin{array}{c}\text { 83\% of diazinon } \\
(20 \mathrm{mg} / \mathrm{L}) \text { was } \\
\text { degraded within } 2 \mathrm{~h}\end{array}$ & Maleki et al., 2020 \\
\hline $\begin{array}{l}\text { Chemically } \\
\text { modified } \\
\text { phosphoric } \\
\text { acid adsorption }\end{array}$ & $\begin{array}{c}5.0 \mathrm{~g} / \mathrm{L} \text { of } \\
\text { adsorbent } \mathrm{pH}=7\end{array}$ & $\begin{array}{l}\text { 98.96\% of diazinon } \\
(1.0 \mathrm{mg} / \mathrm{L}) \text { was } \\
\text { degraded within } 2 \mathrm{~h}\end{array}$ & $\begin{array}{c}\text { Baharum et al., } \\
2020\end{array}$ \\
\hline $\begin{array}{l}\text { Adsorption of } \\
\text { multi-walled } \\
\text { carbon } \\
\text { nanotubes }\end{array}$ & $\begin{array}{c}0.1 \mathrm{~g} / \mathrm{L} \text { of } \\
\text { adsorbent } \mathrm{pH}=4\end{array}$ & $\begin{array}{c}\text { 99.1\% of diazinon } \\
(0.3 \mathrm{mg} / \mathrm{L}) \text { was } \\
\text { degraded within } \\
15 \mathrm{~min}\end{array}$ & $\begin{array}{l}\text { Dehghani et al., } \\
2019\end{array}$ \\
\hline
\end{tabular}

of researchers use a mixture of biochar, activated carbon, minerals, clays, and certain metal-organic frameworks (MOFs) as adsorbents to remove pesticide residues (Abdelhameed et al., 2017; Derylo-Marczewska et al., 2017; Abdelhameed et al., 2019; Durán et al., 2019; Emam and Shaheen, 2019; Baharum et al., 2020). Biochar is prepared from agricultural and forestry production wastes such as raw biomass materials (Ponnam et al., 2020). It has the advantages of loose and porous features, a large specific surface area and high surface energy, which can greatly improve the removal efficiency (Ding et al., 2017). It is one of the adsorbents for pesticide removal (Baharum et al., 2020; 
Okoya et al., 2020). In addition, it can effectively remove organic pollutants in water, such as dyes and drug compounds (Tran et al., 2020; Wu et al., 2020).

Previous research has shown that organic materials play an important role in the use of agricultural waste to remove pesticides. Using waste coconut biomass for modification, carbonized blonde shell biochar (BC1), activated blonde shell biochar (BC2), chemically modified phosphoric acid (BC3), and sodium hydroxide blonde shell biochar (BC4) were prepared as adsorbents for the removal of diazinon (Baharum et al., 2020). When the $\mathrm{pH}$ was 7 , the dosage was $5.0 \mathrm{~g} / \mathrm{L}$, and the adsorbent was BC3, the removal rate of diazine reached $98.96 \%$. Similarly, a large amount of agricultural waste can be used for pesticide removal, such as corn stalks, rice stalks, discarded orange peel, almonds, wood derivatives, birch and Norwegian spruce, bamboo flakes, and even poultry dung, all of which have achieved good results (Liu et al., 2015; Cederlund et al., 2016; Mandal et al., 2017; Suo et al., 2019; Abdelhamid et al., 2020).

Due to the transfer of diazinon from the liquid phase to the solid phase in the adsorption process, secondary contamination can easily occur, which can increase the treatment cost. Photocatalysis is a pesticide removal technology exhibiting complete oxidation, a simple product structure, high efficiency, and a low-cost catalyst, as well as reducing secondary pollution and simultaneously destroying organic pollutants. Mirmasoomi et al. (2017) reported a maximum photocatalytic degradation rate of diazinon of up to $95.07 \%$ using a $\mathrm{TiO}_{2} / \mathrm{Fe}_{2} \mathrm{O}_{3}$ nanocomposite as a catalyst under visible light conditions. Mohagheghian et al. (2016) investigated the photodegradation of diazinon with nano$\mathrm{WO}_{3}$ powder as a catalyst under ultraviolet light irradiation, and the removal efficiency was unexpectedly much higher. Phuong et al. (2019) showed that the initial concentration was set at $25 \mathrm{mg} / \mathrm{L}$ and the degradation rate was 58.3 in $\mathrm{Fe}-\mathrm{TiO}_{2} / \mathrm{Bent}-\mathrm{Fe}$ photocatalysis. Nakaoka et al. (2010) reported that the removal rate of diazinon was approximately $88 \%$ after $30 \mathrm{~h}$ of treatment with platinized $\mathrm{TiO}_{2}$ as the catalyst using UV irradiation. Maleki et al. (2020) studied $\mathrm{WO}_{3}$-doped $\mathrm{ZnO}$ photocatalysis, in which the mineralization rate of $20 \mathrm{mg} / \mathrm{L}$ diazinon under $\mathrm{UV}$ irradiation reached $89 \%$. The ozone degradation of diazinon is performed using nanometal oxides as catalysts, and it generates a variety of active free radicals, which accelerate the additional reaction of hydroxyl radicals and the oxidation of the phosphate group, which is, in turn, conducive to the removal of diazinon (Malakootian et al., 2020). However, a change in external conditions will cause a reduction in free radicals and stimulate the reaction competition of hydroxyl radicals.

Recently, researchers not only continued to optimize the treatment of diazinon but also carried out in-depth studies on its degradation mechanism, which provides a greater scientific basis for our review.

\section{Physico-Chemical Degradation Mechanism of Diazinon}

With the increasing amount of attention being paid to diazinon, abiotic hydrolysis has become one of its main degradation pathways. Under acidic or alkaline conditions, the nitrogen and phosphorus groups in diazinon are activated by pyrimidine protons, which initiate nucleophilic attacks, break the phosphorus and oxygen bonds, and eventually cause rapid hydrolysis. At higher $\mathrm{pH}$ values, the excitor of the nucleophilic attack may be one of the sulfur, benzene, nitrooxy, or pyrimidine protons. The hydrolysates in these cases are the less toxic 2-isopropyl-6-methyl-4-quill (IMP) and diethyldithiophosphoric acid. Consequently, several treatment methods for the degradation of diazinon have been suggested, such as chlorination, ultrasonic irradiation, Fenton's reagent, photoFenton, $\mathrm{UV} / \mathrm{O}_{3}, \mathrm{UV} / \mathrm{H}_{2} \mathrm{O}_{2}, \mathrm{UV} / \mathrm{ZnO}, \mathrm{UV} / \mathrm{TiO}_{2}$, $\mathrm{UV} / \mathrm{ZnO} / \mathrm{TiO}_{2}$, and solar/advanced oxidation processes (AOPs), each of which provide efficient degradation of diazinon ( $\mathrm{Li}$ et al., 2015; Alvarez-Corena et al., 2016; Soto-Vázquez et al., 2016; Hossaini et al., 2017; Shirzad-Siboni et al., 2017; Tabasideh et al., 2017; Ayoubi-Feiz et al., 2018). In AOPs, UV/ $\mathrm{H}_{2} \mathrm{O}_{2}$ is considered to be an effective method for the treatment of organophosphorus pesticide and other micro-organic pollutants (Shemer and Linden, 2006). In the presence of ultraviolet light, the hydrophobic part of natural organic matter (NOM) in water was destroyed, and hydrophilic or polar degradants were generated (Wols and Hofman-Caris, 2012), while haloacetic acid formation increased upon chlorination, which was conducive to the degradation of diazino-organic pesticides. In addition, compared with direct $\mathrm{UV}$ photolysis, the $\mathrm{UV} / \mathrm{H}_{2} \mathrm{O}_{2}$ combined process can mineralize diazinon to a higher degree (Sarathy and Mohseni, 2010).

Sajjadi et al. (2019) used a $\mathrm{Fe}_{3} \mathrm{O}_{4} @ \mathrm{MOF}-2$ nanocomposite (MOF: metal-organic framework) as a catalyst to excite persulfate (PS) under ultrasonic radiation (US) and acidic conditions, which increases the photocatalytic activity and enhances the generation of hydroxyl sulfate radicals in an aqueous solution. Combined with ultrasonic acoustic cavitation, hydroxy easily reacts with $\mathrm{H}_{2} \mathrm{O}$ and $\mathrm{O}_{2}$ to generate $\mathrm{H}_{2} \mathrm{O}$ and $\mathrm{H}_{2} \mathrm{O}_{2}$, thus promoting the decomposition of organic pollutants (Sajjadi et al., 2019). Similarly, under UV and US irradiation, the absorption of photons on the surface of the $N$-doped $\mathrm{TiO}_{2}$ catalyst increases, the availability of active sites on the surface of $\mathrm{TiO}_{2}$ increases, and photoactivated light permeates into the suspension, having a positive effect on the ACo photocatalytic degradation of diazinon (Ayoubi-Feiz et al., 2018). In the $\mathrm{UV} / \mathrm{Cu}$-doped $\mathrm{ZnO}$ process system, the shortcomings of $\mathrm{ZnO}$ nanoparticles as nanocatalysts are overcome. The dissolved oxygen is transformed into superoxide anion $\left(\mathrm{O}_{2}{ }^{-}\right)$, and then, the excited electrons in the photocatalyst react with the electrons in the reaction system, inhibiting the recombination of positive holes and electrons. The degradation efficiency is as high as $96.97 \%$, which is more valuable than the $\mathrm{UV} / \mathrm{ZnO}$ process (Jonidi-Jafari et al., 2015). Hossaini et al. (2017) reported that the cns- $\mathrm{ZnO} / \mathrm{LED}$ process could reduce the accumulation of diazinon in the environment as the system's specific surface area increased by approximately 30\%, meaning that LED radiation can activate more reaction sites. In addition, Liu et al. (2009) found that acid sites were provided in the structure where the catalyst existed, preventing the generation of electron-hole compounds and improving the removal efficiency of organic pollutants. At present, active photocatalysts for photocatalytic degradation of organic and inorganic pollutants are limited to certain metals and nonmetallic substances, such as titanium, 
tungsten oxide, zinc oxide, iron oxide, cadmium sulfide and zinc sulfide, which are gradually introduced (Daneshvar et al., 2007; Sajjad et al., 2018; Khoiriah et al., 2020; Maleki et al., 2020).The ZnO@SiO2@Fe3O4/PMS/UV system is beneficial to the decomposition of oxidizing agents, and a variety of reactive oxidizing species $\left(\mathrm{H} \cdot \mathrm{HO} \cdot \mathrm{O}_{2} \cdot{ }^{-}, \mathrm{SO}_{4} \cdot{ }^{-}\right)$are involved in the degradation of diazinon. $\mathrm{H} \cdot$ and $\mathrm{HO} \cdot$ species play a leading role in diazinon degradation (Daneshvar et al., 2007; Rezaei et al., 2019; Maleki et al., 2020). A number of studies have reported that ozone is a strong oxidant with a redox potential of $2.07 \mathrm{~V}$, which can be combined with $\mathrm{UV}, \mathrm{H}_{2} \mathrm{O}_{2}$ and other processes to destroy ozone and generate more $\mathrm{HO}$. radical oxidation of diazinon to form short-chain compounds (Ayoubi-Feiz et al., 2019; El Hassani et al., 2019; Malakootian et al., 2020).

These combined technologies have been tested and successfully applied to the treatment of diazinon-contaminated sites. Due to their high efficiency, high safety index and positive environmental benefits, the degradation products and pathways of diazinon have been explored (Badawy et al., 2006; Alvarez-Corena et al., 2016; Soto-Vázquez et al., 2016; Orge et al., 2017). The formation of intermediate products for the degradation of diazinon has been widely reported. Arief et al. (2015) showed that the intermediate diazoxon could be rapidly hydrolyzed under both acidic and alkaline conditions, but it was unstable under ultraviolet light conditions and could be oxidized to form diazoxon, but that its toxicity was stronger than that of the parent compound (Okoli et al., 2017). Li et al. (2015) reported that diazinon is hydrolyzed to form ((Z)-3-((E)-1-hydroxy-2-methylpropylidene)amino)but-2-

enimidic acid (IMP) in a $\mathrm{UV} / \mathrm{H}_{2} \mathrm{O}_{2}$ combination by means of cleavage of the $\mathrm{P}-\mathrm{O}$ bond (pyrimidine ring). With further control of the system of the environmental conditions, hydrogen base and oxhydryl participates in the additional reaction of IMP, the formation structure is relatively simple, 2-isopropyl-6-4-ol methylhexahy- dropyrimidin-, (((Z)-3-(Z)1- hydroxy-2-methylpropylidene) amino) but-2-enoic acid, 6-methylhexahydropyrimidine-2,4-diol, (Z)-3-((Z)-1-amino2-methylpropylidene) amino) but-2-enoic acid. Rezaei et al. (2019) also reported another pathway of diazinon, in which hydroxyl diazinon and 2-hydroxyl diazinon can be generated by hydroxylating primary and tertiary carbon atoms of the propyl group, and then the hydroxyl radical acts on the $\mathrm{O}$ functional group and diazinon is hydrolyzed to produce diethyl phosphate and IMP.

In general, the degradation pathway of diazinon is mainly the substitution of sulfur by oxygen in the $\mathrm{P}=\mathrm{S}$ bond, hydroxylated oxidation of the C-N bond, and cleavage of the C-O bond. Previously, the main degradation products of diazinon were hydroxydiazoxon and IMP. The specific degradation path of diazinon is shown in Figure 2.

\section{MICROBIAL DEGRADATION OF DIAZINON}

Although the above abiotic degradation methods can achieve a high removal efficiency, there are still some problems, such as the high cost of equipment, uncertainty regarding intermediate products and incomplete mineralization (Chen et al., 2012; Zhan et al., 2018b; Bhatt et al., 2021a). Therefore, microbial degradation technology is favored because of the distinct advantages of being low-cost, safe, and effective, providing complete degradation and producing no secondary pollution (Liu et al., 2007; Qiu et al., 2018; Roman et al., 2019).

Bacteria, fungi, actinomycetes, and algae that can remove diazinon were obtained by enrichment cultures (Cycoń et al., 2009; Pourbabaee et al., 2018; Hamad, 2020). Diazinonspecific degrading microorganisms are shown in Table 3. Researchers have used enrichment techniques to search for microorganisms that can be used to mineralize diazinon to reduce the concentrations of diazinon in soil agricultural wastewater discharge systems, seawater systems, and heavy industry (Briceño et al., 2015; Wang and Liu, 2016). However, only a small number of microorganisms have been isolated and identified.

These toxic chemicals can be transformed/degraded by bacteria and fungi to form microtoxic or nontoxic small molecules (Dar et al., 2019; Huang et al., 2020; Zhang et al., 2021). Bacteria have been widely used in the bioremediation of pesticides because of their strong biochemical behavior, multiadaptability, and reproductive ability (Dzionek et al., 2016; Cycoń et al., 2017; Lin et al., 2020). Under normal circumstances, a single strain can achieve complete degradation of diazinon (Cycoń et al., 2009). Ralstonia sp. DI-3 is a highly efficient diazinon-degrading bacterium isolated from agricultural soil. It can completely degrade diazinon at an initial concentration of $100 \mathrm{mg} / \mathrm{L}$ after just $60 \mathrm{~h}$ of liquid culture (Wang and Liu, 2016). This result is similar to the report of Abo-Amer (2012). When a small amount of glucose is added exogenously, it can promote the biodegradation of diazinon as a helper substrate (Cycoń et al., 2009). It has been shown that Serratia liquifera, Serratia marcescens, and Pseudomonas can use diazinon as the only carbon source in a mineral salt medium (MSM) containing $50 \mathrm{mg} / \mathrm{L}$ diazinon. These strains were able to degrade $80-92 \%$ of pesticides within 14 days (Cycoń et al., 2009). Bacillus amyloliquefaciens YP6, a growth-promoting rhizosphere bacterium, has been reported to effectively degrade organophosphorus pesticides (OPS). Seo et al. (2007) reported that Arthrobacter and Mycobacterium isolated from petroleum-contaminated soils were very effective in increasing the rate of diazinon mineralization. It was also found that Arthrobacter could not only hydrolyze diazinon but also remove other organophosphorus pesticides (such as chlorpyrifos, acetophosphorus, isophos and parathion).

For Serratia marcescens DI101 in a minimal salt medium, $50 \mathrm{mg} / \mathrm{L}$ diazinon was completely degraded in a period of 11 days compared to Stenotrophomonas sp. G1 strains, which degraded $50 \mathrm{mg} / \mathrm{L}$ diazinon within $24 \mathrm{~h}$ (Deng et al., 2015). Furthermore, it is worth noting that S. marcescens is key in the generation of diethyl phosphate, with organic phosphorus sulfur as a source of carbon bonds and phosphorus, such as chlorpyrifos coumaric, phosphorus parathion, and different nitrogen and phosphorus compounds in this category (Abo-Amer, 2011). The specificity of Stenotrophomonas sp. G1 metabolism is also related 
TABLE 3 | Indigenous microbial strains involved in diazinon degradation.

Microbial strains

Strain type Source

Comments

References

Lactobacillus brevis

Bacterium

Center of Lactic Acid Bacteria

in Key Laboratory of Dairy

University, China

Stenotrophomonas sp.

Ochrobactrum sp.

Serratia marcescens Dl101

Leuconostoc mesenteroides, L. brevis,

L. plantarum, L. sakei

Serratia liquefaciens, S. marcescens,

Pseudomonas sp.

Arthrobacter sp., Mycobacterium sp.

Streptomyces sp. AC1-6., Streptomyces

$\mathrm{sp}$. ISP4

Flavobacterium

sp. ATCC 27551

Ralstonia sp. DI-3

Stenotrophomonas maltophilia

Bacillus amyloliquefaciens YP6

Pseudomonas citronellolis strain ADA-23B Bacterial endophytes in rice plant (Oryzia sativa L.)

Pseudomonas putida D3

Pseudomonas peli, Burkholderia

caryophylli, and Brevundimonas diminuta

Alcaligenes faecalis DSP3

Bacterium Enterobacter B-14

Aspergillus niger MK640786

Rhodotorula glutinis and Rhodotorula rubra
Science, Northeast Agricultural
Bacterium Industrial sludge (China)

Bacterium Sludge from wastewater (China)

Bacterium Agricultural soil (Saudi Arabia)

Bacterium Kimchi during fermentation

(Korea)

Bacterium Agricultural soil (Poland)

Bacterium Petroleum-contaminated soil (Hilo, Hawaii, United States)

Bacterium Agricultural soil (Chile)

Bacterium Agricultural soil (United States)

Bacterium Agricultural soil (Huaibei, China)

Bacterium

Paddy soils (Mazandaran, Iran

Bacterium

Rhizosphere of Lolium perenne (Guizhou, China)

Bacterium Soil-straw; 1:1, v/v (Mexico)

Bacterium Rasht, Iran

Bacterium Southeastern Iran

Bacterium Soil sample

Bacterium Chemical factory, China

Bacterium Australian soil

Fungus Lake Burullus

Fungus Tomato plants
About 52\% of diazinon (0.6 mg/L) was degraded within $24 \mathrm{~h}$

Zhang et al., 2014

Nearly $100 \%$ of diazinon ( $50 \mathrm{mg} / \mathrm{L}$ ) was degraded within $24 \mathrm{~h}$

Deng et al., 2015

Diazinon (50 mg/L) was completely degraded within 11 days About $74 \%$ of diazinon (100 mg/L) was degraded within 12 days at $\mathrm{pH}=3.65-3.69$

(1) About $80-92 \%$ of diazinon ( $50 \mathrm{mg} / \mathrm{L})$ was degraded within 14 days

(2) Utilizes diazinon as the sole carbon source

(3) Adding other carbon sources (glucose) increases the decomposition rate

These strains can utilize diazinon as growth substrate and transform diazinon.

(1) About $40-50 \%$ of diazinon (25 mg/L) was degraded within $24 \mathrm{~h}$

(2) About $70-90 \%$ of diazinon (50 mg/L) was degraded within $96 \mathrm{~h}$

About $95 \%$ of diazinon $(50 \mathrm{mg} / \mathrm{L})$ was degraded within $24 \mathrm{~h}$

(1) Diazinon (100 $\mathrm{mg} / \mathrm{L})$ was completely degraded within 60 days

(2) Utilizes diazinon as the sole carbon source

(1) Diazinon is the main carbon source $(50 \mu \mathrm{g} / \mathrm{mL})$

(2) About $90 \%$ of diazinon was degraded within 15 days

Increases soluble phosphorus, produces indole-3-acetic acid (IAA) and iron carriers

About $40 \%$ of diazinon $(50 \mathrm{mg} / \mathrm{L})$ was degraded within $16 \mathrm{~h}$

(1) Diazinon (20 mg/L) is the sole carbon source

(2) About $3.79-58.52 \%$ of initial dose was degraded within 14 days

About $91 \%$ of diazinon was degraded $(40 \mathrm{mg} / \mathrm{L}$ ) within 21 days

Diazinon (20 mg/L) was completely degraded within 18 days

About $90 \%$ of diazinon $(100 \mu \mathrm{g} / \mathrm{mL})$ was degraded within 10 days

Diazinon $(25 \mu \mathrm{g} / \mathrm{mL})$ was completely degraded within 2 days

About $82 \%$ of diazinon $(1.25 \mathrm{mg} / \mathrm{L})$ was degraded after 7 days

(2) Optimal conditions for metabolism are $\mathrm{pH}=5,30^{\circ} \mathrm{C}$

(1) During the same period, the initial concentration of diazinon was reduced by $88 \%$ when $R$. glutinis was added compared with the control

(2) During the same period, the initial concentration of diazinon was reduced by

$88 \%$ when $R$, rubra was added compared with the control
Abo-Amer, 2011

Cho et al., 2009

Cycoń et al., 2009

Seo et al., 2007

Briceño et al., 201

Mulbry and Karns, 1989

Wang and Liu, 2016

Pourbabaee et al., 2018

Meng et al., 2019

Góngora-Echeverría et al., 2020

Nasrollahi et al., 2020

Hassanshahian, 2016

Mahiudddin et al., 2014

Yang et al., 2005

Singh et al., 2004

Hamad, 2020

Bempelou et al., 2013

Ehrampoush et al., 2017 


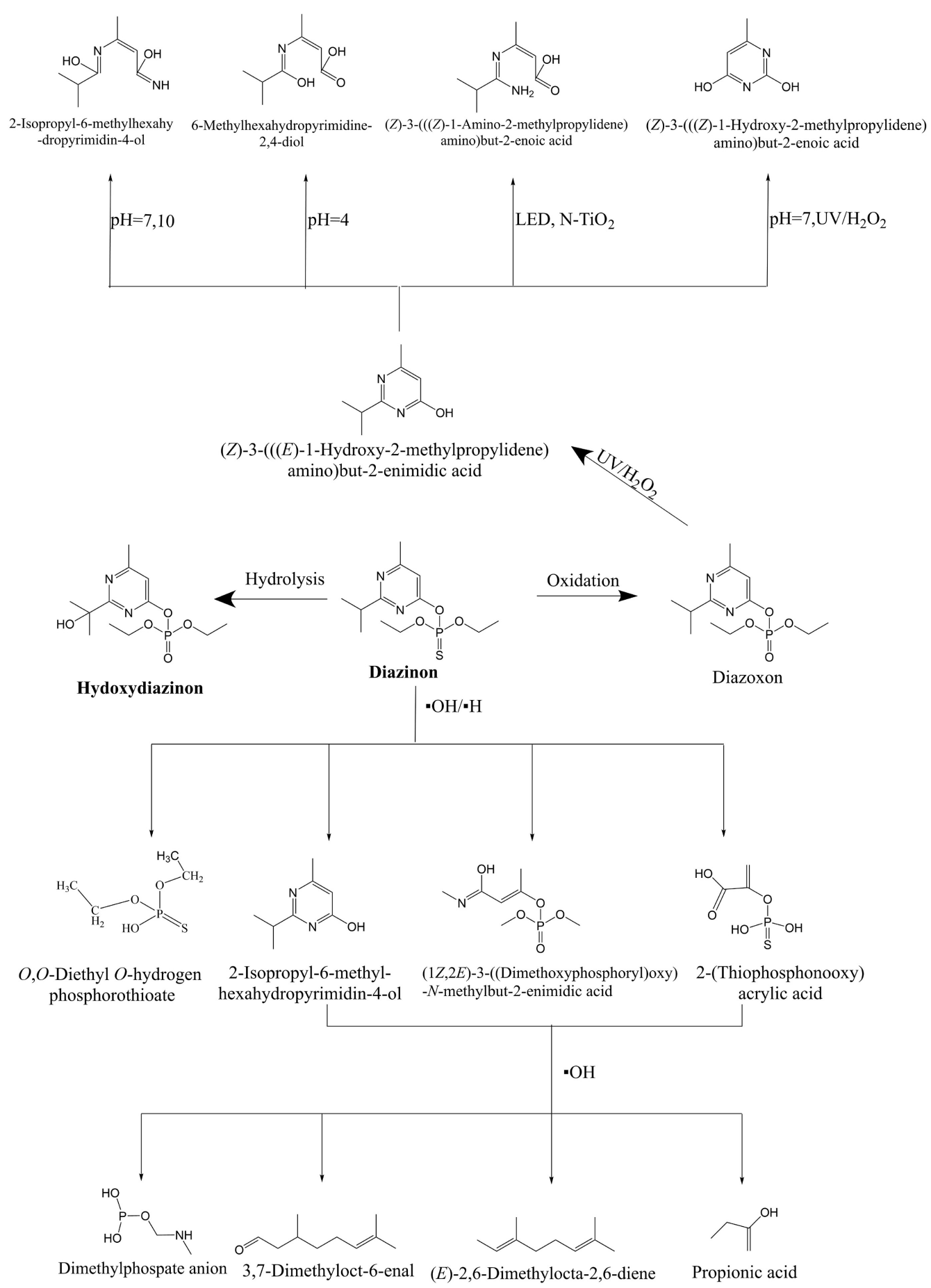

FIGURE 2 | Proposed physico-chemical degradation pathways of diazinon (Arief et al., 2015; Čolović et al., 2015; Malakootian et al., 2020). The thick black arrows point to the major degradation products.

to pesticide structure, which is capable of degrading triphosphate organophosphorus pesticides, such as phoxim methyl p-pparathion methyl p-p-parathion, while the degradation of propiom bromophos and triazophos is relatively slow. Current studies have shown that various bacterial genera, such as
Stenomonas, Serratia, Burkholderia, Rodanobacteria, Reisella, and Pseudomonas, all use diazinon as the only carbon source, which improves the reaction rate and promotes the degradation of diazinon. In addition, bacteria $B$. altitudinis DB26-R and B. subtilis subsp., isolated from various plant tissues (endophytic 
bacteria), have great potential to degrade various compounds (Afzal et al., 2014). They have high degradability potential for diazinon. In recent years and fungi have also been used in the degradation of OPs. Ramadevi et al. (2012) reported that they have broad-spectrum pesticide degradation characteristics, as well as biological safety, economic feasibility and highly efficient degradation activity tolerance and are widely used in the pesticide bioremediation of contaminated soil water systems; they can even grow in contaminated soil water systems with a chlorpyrifos concentration of $700 \mathrm{mg}$. Optimized by response surface methodology, Aspergillus niger MK640786 effectively reduced diazinon and achieved a degradation rate of $82 \%$ under incubation conditions of $30^{\circ} \mathrm{C}$, an initial concentration of $25 \mathrm{mg} / \mathrm{L}$, a $\mathrm{pH}$ value of 5 and an incubation time of 7 days (Chen et al., 2012; Carranza et al., 2016). Aspergillus had different degradation efficiencies of diazinon under different environmental conditions. Culturing in $30^{\circ} \mathrm{C}$ liquid medium for 5 days was not conducive to the degradation of diazinon, and the degradation rate was as low as $46 \%$.

Debasmita and Rajasimman (2013) found that if Aspergillus were incubated for 14 days, the hydrolysis of diazinon could reach $90.02 \%$. On the other hand, fungi, such as Anisoplia bassiana, could degrade $72 \%$ of chlorpyrifos within $132 \mathrm{~h}$ (Shah et al., 2017). The degradation rate was only $35.3 \%$ when cultured in medium containing diazinon for 4 days (Fareed et al., 2017). Ehrampoush et al. (2017) found that Saccharomyces cerevisiae could use diazinon (initial concentration of $1000 \mathrm{mg} / \mathrm{L}$ ) as its carbon source. Diazinon was successfully degraded by S. cerevisiae within $0.5 \mathrm{~h}$ by $85.23 \%$. The degradation rate of carmoisine dye was $96 \%$.

In a pure culture of Streptomyces with a diazinon concentration of $50 \mathrm{mg} / \mathrm{L}$, only $32 \%$ degradation was found, likely because its toxicity is greater than the original byproduct of degradation compounds. As a result, people began to use microbial populations of mixed culture alone or with other populations of common culture techniques in order to avoid the degradation process of the accumulation of toxic compounds, and the degradation effect was better than that of pure culture (Fuentes et al., 2011). When Streptomyces strains AC5, AC9, GA11, and ISP13 were used in a mixed culture (SMC), the degradation rate of diazinon reached the maximum (62\%). Briceño et al. (2016) also investigated the removal effect of Streptomyces mixed cultures in 100 chlorpyrifos $(\mathrm{CP})+$ diazinon (DZ)-contaminated liquid media. This will hopefully be an alternative approach to removing DZ from the environment. This approach uses an inorganic salt medium in which the enrichment cycle is run multiple times and diazinon isolated from paddy soil is mixed with degrading bacteria, consisting of species from Burkholderia, Achromobacter, Hyphomicrobium, Rhodanobacter, and so on. Within cultures of 16.81 and 19.60 days, pesticide degradation achieved favorable results, and the removal rate reached $90 \%$. There are many similar situations reported. In the microbial remediation experiment, it was found that when the mixture of strains degraded diazinon (Briceño et al., 2016), the removal rate of the other four pure strains was the highest (65\%). Abo-Amer (2011) also observed that the pesticide degradation rate of the mixed bacteria reached
99\% within 11 days, which was most likely due to the presence of different types of microorganisms in the mixed flora, such as bacterial archaea and fungi. There were some synergistic mechanisms among these bacteria to promote degradation.

In the process of pesticide degradation, hydrolysis is the main method (Kumar et al., 2018). The possible microbial degradation pathways of diazinon are shown in Figure 3. Various bacterial enzymes, such as acid and alkaline phosphatase, phosphodiesterase, phosphotriesterase (PTE), and dehydrogenase, have the ability to form hydrolytic functional groups in a short time. Combined microbial enzyme action can also achieve a detoxification effect (Briceño et al., 2018). The glutathione S-transferase superfamily is a key enzyme in biological metabolism. The enzyme bmGSTu2 exists in the silkworm Bombyx mori. It is a diazinon-metabolizing enzyme that can combine with 1-chloro-2,4-dinitrobenzene and contribute to the detoxification of diazine (Yamamoto and Yamada, 2016). Carboxylesterase is very effective in the detoxification of organophosphorus insecticides, and its mechanism is mainly divided into the following steps (Wheelock et al., 2008). It is first activated by a mixture of functional oxidases (MFOs) to form an active form of oxon. Second, organophosphorus insecticides combine with esterase and hydrolyze to release nitrophenol. Phosphorylated esterases may release phosphate groups to regain catalytic activity, or they may form phosphate complexes and lose catalytic activity (Wheelock et al., 2005). Both phosphorylase and methylcarbamoylase are helpful in reducing the toxicity of organophosphorus insecticides, but their stability is much higher than that of methylcarbamoylase (Casida and Quistad, 2004). Therefore, in terms of detoxification strength, phosphorylase works better.

\section{MOLECULAR MECHANISM OF DIAZINON BIODEGRADATION}

Microbe-mediated bioremediation and catalysis have been confirmed by the previous literature, and a variety of strains have been used to degrade organophosphorus pesticides and have been found to achieve good remediation effects (Zhan et al., 2018a; Mishra et al., 2020; Huang et al., 2021). The root cause of this is that various strains contain a variety of enzymes that detoxify organophosphorus pesticides, most of which belong to phosphotriesterase (PTE) (da Silva et al., 2013; Birolli et al., 2019). Among them, organophosphorus hydrolase $(\mathrm{OPH})$, methylparathion hydrolase (MPH), organophosphorus anhydrase (OPAA), diisopropyl-fluorophosphatase (DFPase) and paraoxonase 1 (PON1) are all classic degrading enzymes (da Silva et al., 2013; Daczkowski et al., 2015). These enzymes have their own characteristics. Figure 4 describes the evolutionary relationships between the functional enzymes involved in the degradation of diazinon.

To better study the degradation mechanism of enzymes, the most important step is to understand the enzyme itself. OPH is a zinc-containing homodimeric protein (Dumas et al., 1989). OPH carries the OPD gene of Flavobacterium sp. ATCC 27551 


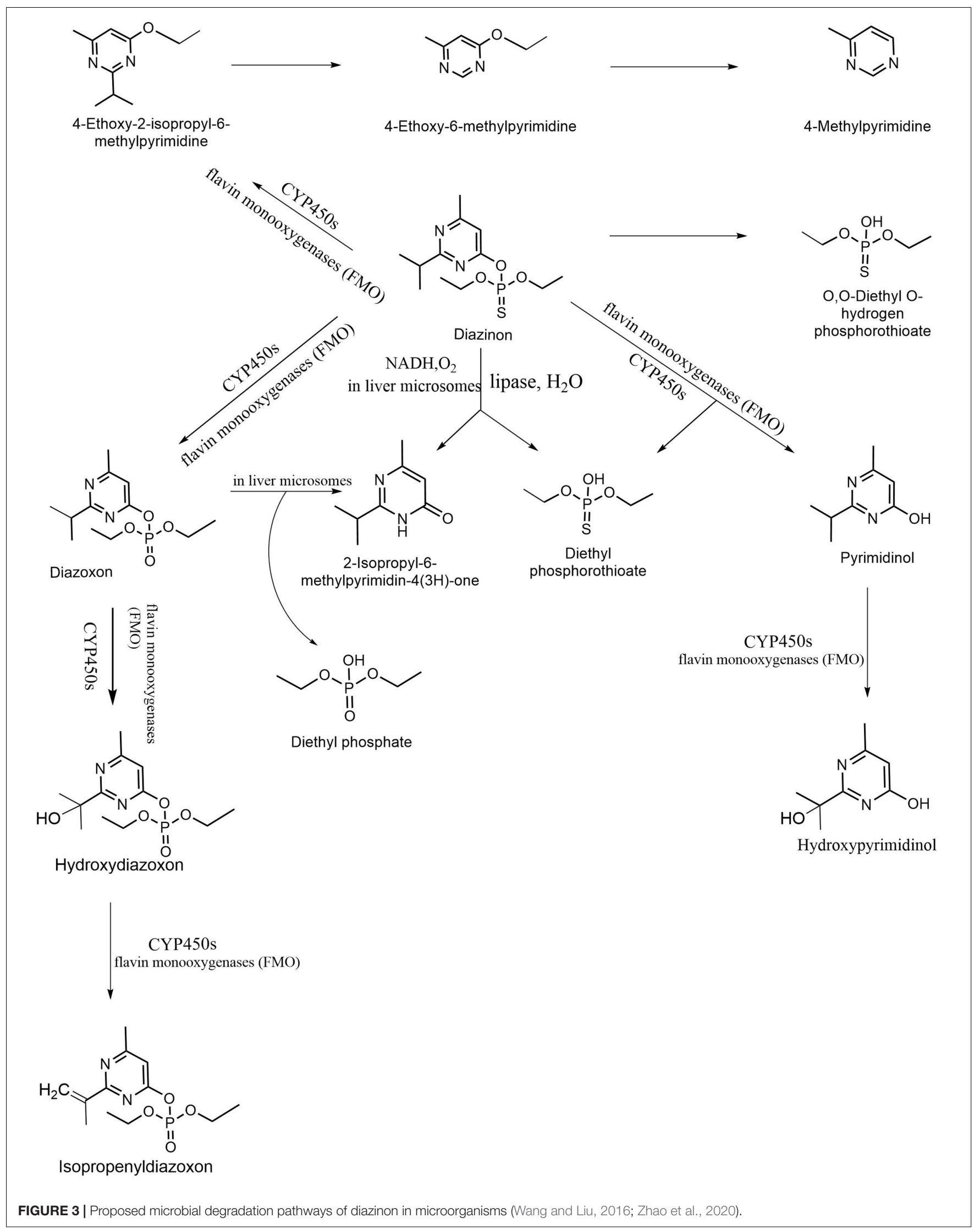




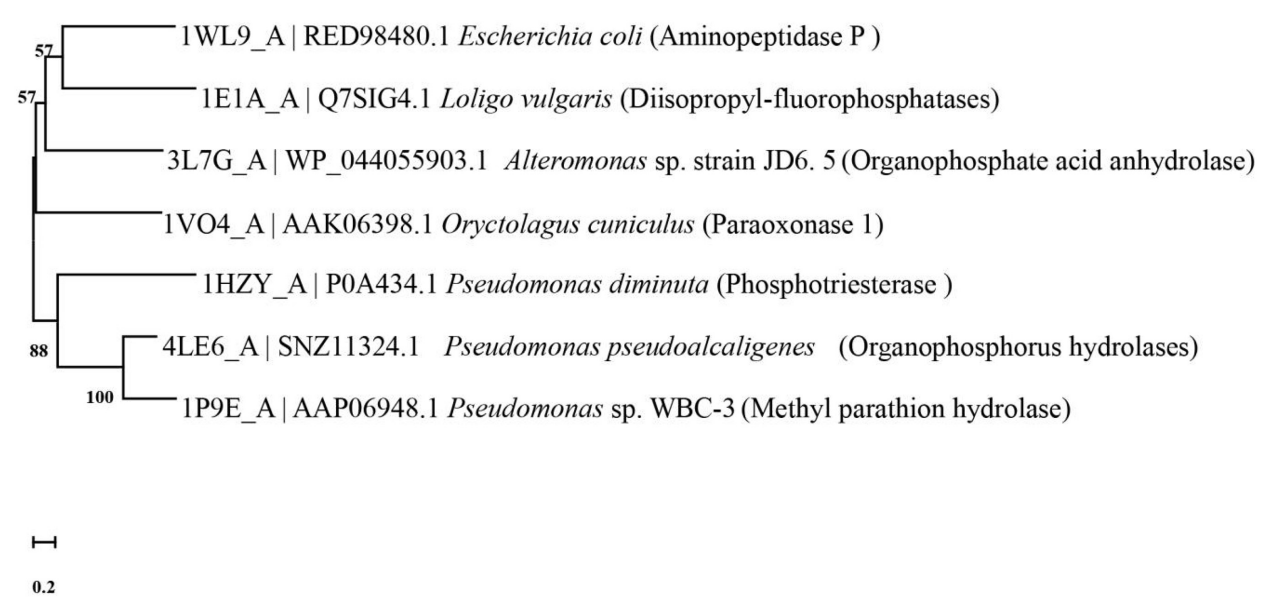

FIGURE 4 | Phylogenetic tree of key diazinon-degrading enzymes constructed by the neighbor-joining method. The code before the strain name is the NCBI accession number. Aminopeptidase P was isolated from Escherichia coli (Graham et al., 2005). Diisopropyl-fluorophosphatase was isolated from Loligo vulgaris (Scharff et al., 2001). Organophosphate acid anhydrolase was isolated from Alteromonas sp. strain JD6.5 (Vyas et al., 2010). Paraoxonase 1 was isolated from Oryctolagus cuniculus (Thakur et al., 2019). Phosphotriesterase was isolated from Pseudomonas diminuta (Benning et al., 2001). Organophosphorus hydrolase was isolated from Pseudomonas pseudoalcaligenes (Gotthard et al., 2013). Methyl parathion hydrolase was isolated from Pseudomonas sp. WBC-3 (Dong et al., 2005).

and B. diminuta MG. It uses $\mathrm{Co}^{2+}, \mathrm{Zn}^{2+}, \mathrm{Mg}^{2+}, \mathrm{Ca}^{2+}$, and $\mathrm{Fe}^{2+}$ for nucleophilic attack, thus hydrolyzing $\mathrm{P}-\mathrm{O}, \mathrm{P}-\mathrm{CN}, \mathrm{P}-\mathrm{F}$, and S bonds (Ghanem and Raushel, 2005; Orbulescu et al., 2006). MPH was isolated from Plesiomonas sp. M6 (M6-mph). Organophosphorus anhydrase (OPAA) is a dipeptidase isolated from Monomonas. With $\mathrm{Mn}^{2+}$ as the ligand, OPAA binds with the substrate to degrade organophosphorus by nucleophilic attack (Thakur et al., 2019). The degradation of DFP by the DFP enzyme may be due to its three histidine residues acting on the active sites of the substrate, of which two histidine residues, $\mathrm{H} 274$ and H174, can act as stabilizers, and H287 can achieve alkaline catalysis (Blum and Chen, 2010). The P-F bonds of the substrate are hydrolyzed gradually, eventually releasing isopropyl phosphate and fluoride (Jacquet et al., 2016). Paraoxonase 1 has the universality of a substrate, and it can degrade the oxon metabolites of parathion, diazinon, and chlorpyriphos (Draganov and La Du, 2004).

Diazinon belongs to the organophosphorus family and has a similar functional group structure. In the degradation of diazinon, each strain has its own degradation mechanism, and the enzyme interaction plays an important role in the catalytic degradation process (Chu et al., 2018; Vera et al., 2020; Zhao et al., 2020). These phosphotriester hydrolases adapt to a wide range of temperatures and $\mathrm{pH}$ values and are involved in the degradation of various OPS substrates. They have been reported to have great advantages in removing pesticides and nerve agents (Kapoor and Rajagopal, 2011; Gao et al., 2012; Lu et al., 2013). As an enzyme that catalyzes the stereoselective hydrolysis of a large number of triphosphate esters (Elias et al., 2008), triphosphoesterase (PTES, E.C. 3.1.8.1) can break the P-O, P-N or P-S bonds (Sogorb et al., 2004). Subsequently, microorganisms in nature use the hydrolysates of Ops as carbon/nitrogen sources (Kumar et al., 2018). Researchers have paid close attention to these hydrolases and proven their presence in microorganisms. By purifying, identifying and cloningrelated genes, organophosphorus diminutases were isolated from Brevundimonas sp., Pseudomonas diminuta, and Flavobacterium sp. Paraoxonases are a class of interesting enzymes. According to sequence homology, PON enzymes can be divided into three groups: PON1, PON2, and PON3, among which PON1 has been the most studied for the degradation of diazinon (Draganov and La Du, 2004; Draganov et al., 2005). Paraoxonase 1 is a highdensity lipoprotein-associated esterase/lactonase, which is also a monomer enzyme with calcium as the binding site. In the process of enzyme catalysis, it preferentially hydrolyzes the bonds of $\mathrm{P}-\mathrm{O}$, $\mathrm{P}-\mathrm{C}, \mathrm{P}-\mathrm{F}$, and P-CN.

The active site of an organophosphorus hydrolase contains one or two metal ions. Catalytic degradation of the substrate with metal ions is achieved through hydrogen bonding and the interaction of two amino acid residues in two active sites, followed by nucleophilic attack by hydroxide ions (Sethunathan and Yoshida, 1973). This also provides some basis for the catalytic triad previously mentioned. Organophosphorus hydrolases have similar active site geometries. The most typical PTE was detected in Flavobacterium sp. ATCC 27551 and P. diminuta, and the sequence homology of OpdA detected by Astrobacterium radiobacter was as high as 90\% (Pedroso et al., 2014). Organophosphorus hydrolases have been confirmed by previous studies to have three amino acid residues to form a catalytic triad, of which the most common is hydroxy-serine residues that function as nucleophile attack substrates (Dar et al., 2019; Bhatt et al., 2021b).

Three important amino acid residues (Ser-His-Thr or Glu) in PTE form the catalytic triad (Bhatt et al., 2020a). First, the substrate interacts with metal ions (hydrogen bonding) to activate hydroxy-serine residues. The reactive oxygen atoms on the serine residue nucleophilically attack the phosphorus atoms on diazinon, forming the diazinon-hydrolase complex 


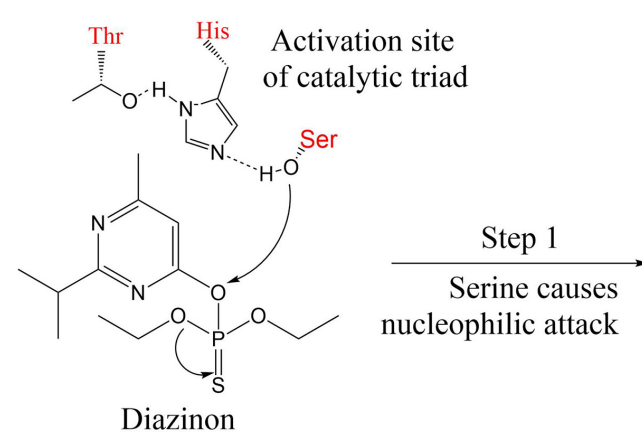

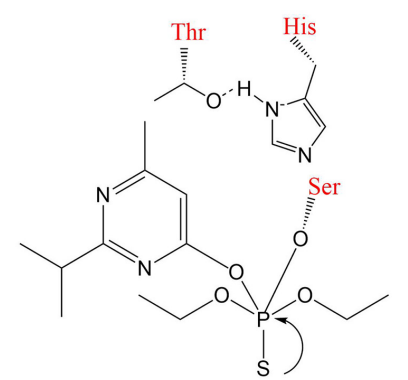

Diazinon-hydrolase complex<smiles>CCOP(=S)(OCC)OCCCCCC(C)C</smiles>

Tetrahedral intermediate Step 4<smiles>CC(Br)ONn1cncc1C[18O]</smiles><smiles>Oc1ccccc1</smiles>

Free active site amino acid $+$

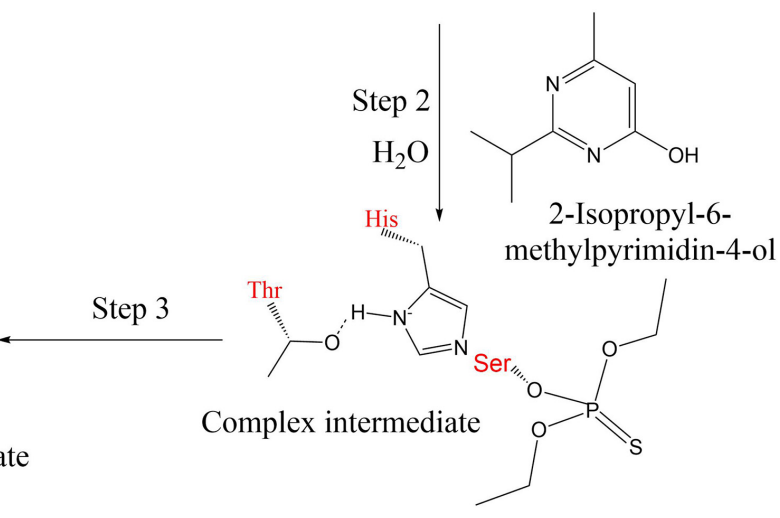

Complex intermediate

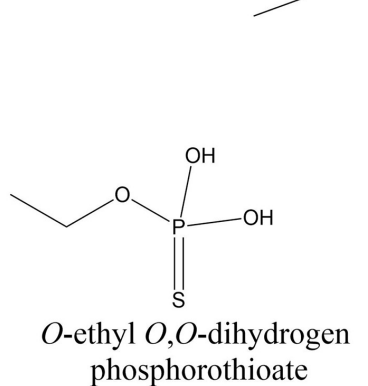
phosphorothioate

FIGURE 5 | The specific enzymatic catalytic process of diazinon. The active site of organophosphorus hydrolase contains three amino acids (serine, histidine, threonine or glutamine) (Bhatt et al., 2020a; Huang et al., 2021). The hydroxyl group of serine takes part in nucleophilic reactions during diazinon biodegradation.

(Islam et al., 2010). In the second step, hydroxide in the water molecule acts as a nucleophile, occupying the original active site of serine, while histidine acquires hydrogen protons (Huang et al., 2021). The remaining hydroxide continues to nucleophilically attack the phosphorus-oxygen bond, releasing the intermediate 2-isopropyl-6-methylpyrimidin-4-ol. During the third step, the serine activity decreased and returned to the resting state. A complex intermediate is present in the system (Zhan et al,, 2020; Bhatt et al., 2021c). The oxygen atom in the phosphoric acid group is connected to the nitrogen atom in the base by a hydrogen bond, and the intermediate product is tetrahedral in configuration. In the last step, alcohols and free amino acids are separated from the complex through protonation, resulting in the detoxification of the toxic organophosphorus pesticide diazinon. The specific enzymatic catalytic process is shown in Figure 5.

The aryl dialkyl phosphatase (ADPB) isolated from Nocardia strain B-L is different from the former. Organic phosphate dehydrogenase is a dipeptidase isolated from both Alteromonas undina and Alteromonas haloplankton, and it has a relatively low hydrolysis rate (Cheng et al., 1993). In addition, methyl parathion hydrolase (MPH), isolated from Plesiomonas sp. M6 plays an important role in the hydrolysis of many $\mathrm{OP}_{S}$, including methyl parathion, chlorpyrifos, thiophos and diazinon (Cui et al., 2001; Liu et al., 2005). Chu et al. (2010) isolated another hydrolase from Pseudomonas pseudoaligenes strain $\mathrm{C}_{2-1}$. Interestingly, this enzyme was encoded by the ophc2 gene and had $46.4 \%$ similarity with the MPH gene. Sogorb and Vilanova (2002) believe that amylase from Bacillus amyloliquefaciens YP6 contains a variety of promising genes, including soluble phosphorus and $\mathrm{OP}_{S}$ degradation-related genes. In the process of microalgae degradation of $\mathrm{OP}_{S}$, it was observed that when the wavelength was $600 \mathrm{~nm}$, the OD value increased linearly with time and the activity of carboxylesterase in microalgae increased, thus promoting $\mathrm{OP}_{\mathrm{S}}$ to generate phosphate (Kumar et al., 2018). 
The existence of a variety of hydrolase genes (phoD, phoA, phrC, phoE, $y c s \mathrm{E}, b c r \mathrm{C}$, and $y v a \mathrm{~K})$ in microbial cells proves that microorganisms have potential advantages in agricultural environmental remediation, along with biosynthesis-related genes $(a m h \mathrm{X}, c g e \mathrm{E}$ and eps $\mathrm{M})$ and iron carrier biosynthesisrelated genes (ent $\mathrm{B}$, men $\mathrm{F}$, ent $\mathrm{C}$ and ent $\mathrm{A}$ ) (Sogorb and Vilanova, 2002; Idris et al., 2007; Chu et al., 2018). At present, we have found a variety of degrading enzymes and their related genes, but most of them describe the degradation of a single enzyme. Some individual enzymes were unstable and could not be developed into industrial strains. Therefore, increasing efforts are required to carry out genetic modification according to the characteristics of these enzymes to improve their activity and tolerance to ensure the efficient degradation of organic pollutants. The genetic engineering mechanism of the strain needs to be further explored.

\section{CONCLUSION AND FUTURE PERSPECTIVES}

In recent years, diazinon has occupied an important position in the list of pesticides worldwide, and its high toxicity and high residue cannot be ignored. Currently, many physical and chemical methods have been applied to eliminate diazinon, but some challenges remain, such as high equipment cost, uncertainty regarding intermediates and incomplete mineralization. Therefore, an eco-friendly, economic, and feasible processing method is required for the sustainable degradation of diazinon. Microorganisms, including bacteria, fungi, and algae, are widely used in the degradation of diazinon. Biochemical and genetic research into diazinon-degrading microbes is necessary. The degradation ability of pure culture strains was always limited, while the degradation effect of microorganisms, including bacteria, fungi and algae, in a mixed

\section{REFERENCES}

Abdelhameed, R. M., Abdel-Gawad, H., Taha, M., and Hegazi, B. (2017). Separation of bioactive chamazulene from chamomile extract using metalorganic framework. J. Pharm. Biomed. Anal. 146, 126-134. doi: 10.1016/j.jpba. 2017.08.020

Abdelhameed, R. M., Taha, M., Abdel-Gawad, H., Mahdy, F., and Hegazi, B. (2019). Zeolitic imidazolate frameworks: experimental and molecular simulation studies for efficient capture of pesticides from wastewater. J. Environ. Chem. Eng. 7:103499. doi: 10.1016/j.jece.2019.103499

Abdelhamid, F. M., Elshopakey, G. E., and Aziza, A. E. (2020). Ameliorative effects of dietary Chlorella vulgaris and $\beta$-glucan against diazinon-induced toxicity in Nile tilapia (Oreochromis niloticus). Fish Shellfish Immun. 96, 213-222. doi: 10.1016/j.fsi.2019.12.009

Abo-Amer, A. (2011). Biodegradation of diazinon by Serratia marcescens DI101 and its use in bioremediation of contaminated environment. J. Microbiol. Biotechnol. 21, 71-80. doi: 10.4014/jmb.1007.07024

Abo-Amer, A. E. (2012). Characterization of a strain of Pseudomonas putida isolated from agricultural soil that degrades cadusafos (Anorganophosphorus pesticide). World J. Microbiol. Biotechnol. 28, 805-814. doi: 10.1007/s11274011-0873-5

Adamovsky, O., Buerger, A. N., Wormington, A. M., Ector, N., Griffitt, R. J., and Bisesi, J. H. (2018). The gut microbiome and aquatic toxicology: an emerging concept for environmental health. Environ. Toxicol. Chem. 37, 2758-2775. doi: $10.1002 /$ etc. 4249 culture was more efficient. In the future, the application of gene modification, mixed cultures of bacteria and immobilization technology will be a relatively popular research field, which has significance for the development of bioremediation strategies for diazinon-contaminated soil. On the one hand, immobilized enzyme technology will improve the stability of enzyme activity and expand the $\mathrm{pH}$ value and temperature range of the enzyme to adapt to better degradation of pollutants. On the other hand, we can construct transgenic vectors to transfer biodegradable genes into organisms that are easy to manipulate and stable. The degradation gene can be fully expressed to effectively remove pollutants. In addition, we can fully mobilize the synergistic or antagonistic effects in the mixed bacteria to achieve efficient degradation of organic pollutants. Furthermore, the development of recent sequencing techniques could add to and accelerate the prediction of the molecular-level mechanism involved in diazinon degradation.

\section{AUTHOR CONTRIBUTIONS}

SC conceived the presented idea. XW contributed to the writing and prepared the figures and tables. ZL, SP, JL, ZZ, PB, SM, and $S C$ participated in revising the manuscript. All authors approved it for publication.

\section{FUNDING}

This study was supported by grants from the Key Realm R\&D Program of Guangdong Province (2018B020206001 and 2020B0202090001), the Natural Science Foundation of Guangdong Province (2021A1515010889), and the Guangdong Special Support Program (2017TQ04N026).

Afzal, M., Khan, Q. M., and Sessitsch, A. (2014). Endophytic bacteria: prospects and applications for the phytoremediation of organic pollutants. Chemosphere 117, 232-242. doi: 10.1016/j.chemosphere.2014 .06 .078

Ahmadifard, T., Heydari, R., Tarrahi, M. J., and Khorramabadi, G. (2019). Photocatalytic degradation of diazinon in aqueous solutions using immobilized MgO nanoparticles on concrete. Int. J. Chem. React. Eng. 17:9. doi: 10.1515/ ijcre-2018-0154

Alalm, M. G., Tawfik, A., and Ookawara, S. (2015). Combined solar advanced oxidation and PAC adsorption for removal of pesticides from industrial wastewater. J. Environ. Sci. 6, 800-809.

Al-Otaibi, A. M., Al-Balawi, H. F. A., Ahmad, Z., and Suliman, E. M. (2019). Toxicity bioassay and sub-lethal effects of diazinon on blood profile and histology of liver, gills and kidney of catfish Clarias gariepinus. Braz. J. Biol. 79, 326-336. doi: 10.1590/1519-6984.185408

Alvarez-Corena, J. R., Bergendahl, J. A., and Hart, F. L. (2016). Advanced oxidation of five contaminants in water by UV/TiO2: reaction kinetics and byproducts identification. J. Environ. Manage. 181, 544-551. doi: 10.1016/j.jenvman.2016. 07.015

Arellano-Aguilar, O., Betancourt-Lozano, M., Aguilar-Zárate, G., and Ponce de Leon-Hill, C. (2017). Agrochemical loading in drains and rivers and its connection with pollution in coastal lagoons of the Mexican Pacific. Environ. Monit. Assess. 189, 270. doi: 10.1007/s10661-017-5981-8

Arias-Andrés, M., Rämö, R., Mena Torres, F., Ugalde, R., Grandas, L., Ruepert, C., et al. (2018). Lower tier toxicity risk assessment of agriculture pesticides 
detected on the Río Madre de Dios watershed, Costa Rica. Environ. Sci. Pollut. Res. 25, 13312-13321. doi: 10.1007/s11356-016-7875-7

Arief, M., Slaeh, M., and Ismail, I. (2015). Study the relation between storage and stability of diazinonemulsifiable concentrate formulations in the formation of its impurities and major degradation products. Int. J. Adva. Res. 3, 247-261.

Aronzon, C. M., Marino, D. J. G., Ronco, A. E., and Coll, C. S. P. (2014). Differential toxicity and uptake of diazinon on embryo-larval development of Rhinella arenarum. Chemosphere 100, 50-56. doi: 10.1016/j.chemosphere.2013.12.078

Arora, P. K. (2020). Bacilli-mediated degradation of xenobiotic compounds and heavy metals. Front. Bioeng. Biotech. 8:570307. doi: 10.3389/fbioe.2020.570307

Ayoubi-Feiz, B., Mashhadizadeh, M. H., and Sheydaei, M. (2018). Preparation of reusable nano $\mathrm{N}-\mathrm{TiO} 2 /$ graphene/titanium grid sheet for electrosorptionassisted visible light photoelectrocatalytic degradation of a pesticide: effect of parameters and neural network modeling. J. Electroanal. Chem. 823, 713-722. doi: 10.1016/j.jelechem.2018.07.020

Ayoubi-Feiz, B., Mashhadizadeh, M. H., and Sheydaei, M. (2019). Degradation of diazinon by new hybrid nanocomposites $\mathrm{N}-\mathrm{TiO} 2 / \mathrm{Graphene} / \mathrm{Au}$ and $\mathrm{N}$-TiO2/Graphene/Ag using visible light photo-electro catalysis and photoelectro catalytic ozonation: optimization and comparative study by Taguchi method. Sep. Purif. Technol. 211, 704-714. doi: 10.1016/j.seppur.2018.10.032

Badawy, M. I., Ghaly, M. Y., and Gad-Allah, T. A. (2006). Advanced oxidation processes for the removal of organophosphorus pesticides from wastewater. Desalination 194, 166-175. doi: 10.1016/j.desal.2005 .09 .027

Baharum, N. A., Nasir, H. M., Ishak, M. Y., Isa, N. M., Hassan, M. A., and Aris, A. Z. (2020). Highly efficient removal of diazinon pesticide from aqueous solutions by using coconut shell-modified biochar. Arab. J. Chem. 13, 6106-6121. doi: 10.1016/j.arabjc.2020.05.011

Bakırcı, G. T., Yaman Acay, D. B., Bakırcı, F., and Ötleş, S. (2014). Pesticide residues in fruits and vegetables from the Aegean region, Turkey. Food Chem. 160, 379-392. doi: 10.1016/j.foodchem.2014.02.051

Bempelou, E., Vontas, J. G., Liapis, K. S., and Ziogas, V. N. (2013). Biodegradation of diazinon by the epiphytic yeasts Rhodotorula glutinis and Rhodotorula rubra. Helle. Plant Prote. J. 6, 69-82.

Benning, M. M., Shim, H., Raushel, F. M., and Holden, H. M. (2001). High resolution X-ray structures of different metal-substituted forms of phosphotriesterase from Pseudomonas diminuta. Biochemistry 40, 2712-2722. doi: $10.1021 / \mathrm{bi002661e}$

Bhatt, P., Rene, E. R., Kumar, A. J., Zhang, W., and Chen, S. (2020b). Binding interaction of allethrin with esterase: bioremediation potential and mechanism. Bioresour. Technol. 315:123845. doi: 10.1016/j.biortech.2020.123845

Bhatt, P., Bhatt, K., Huang, Y., Lin, Z., and Chen, S. (2020a). Esterase is a powerful tool for the biodegradation of pyrethroid insecticides. Chemosphere 244:125507. doi: 10.1016/j.chemosphere.2019.125507

Bhatt, P., Bhandari, G., Bhatt, K., Maithani, D., Mishra, S., Gangola, S., et al. (2021a). Plasmid-mediated catabolism for the removal of xenobiotics from the environment. J. Hazard. Mater 420:126618.

Bhatt, P., Joshi, T., Bhatt, K., Zhang, W., Huang, Y., and Chen, S. (2021b). Binding interaction of glyphosate with glyphosate oxidoreductase and C-P lyase: molecular docking and molecular dynamics simulation studies. J. Hazard. Mater. 409:124927. doi: 10.1016/j.jhazmat.2020.124927

Bhatt, P., Zhou, X., Huang, Y., Zhang, W., and Chen, S. (2021c). Characterization of the role of esterases in the biodegradation of organophosphate, carbamate, and pyrethroid pesticides. J. Hazard. Mater. 411, 125026. doi: 10.1016/j.jhazmat. 2020.125026

Birolli, W. G., Lima, R. N., and Porto, A. L. M. (2019). Applications of marine-derived microorganisms and their enzymes in biocatalysis and biotransformation, the underexplored potentials. Front. Microbiol. 10:1453. doi: $10.3389 /$ fmicb.2019.01453

Blum, M. M., and Chen, J. C. H. (2010). Structural characterization of the catalytic calcium-binding site in diisopropyl fluorophosphatase (DFPase)-comparison with related $\beta$-propeller enzymes. Chem-Biol. Interact. 187, 373-379. doi: 10. 1016/j.cbi.2010.02.043

Briceño, G., Fuentes, M. S., Rubilar, O., Jorquera, M., Tortella, G., and Palma, G. (2015). Removal of the insecticide diazinon from liquid media by free and immobilized Streptomyces sp. isolated from agricultural soil: removal of insecticide diazinon from liquid residues. J. Basic. Microb. 55, 293-302. doi: $10.1002 /$ jobm. 201300576
Briceño, G., Schalchli, H., Rubilar, O., Tortella, G. R., Mutis, A., Benimeli, C. S., et al. (2016). Increased diazinon hydrolysis to 2-isopropyl-6-methyl4-pyrimidinol in liquid medium by a specific Streptomyces mixed culture. Chemosphere 156, 195-203. doi: 10.1016/j.chemosphere.2016.04.118

Briceño, G., Vergara, K., Schalchli, H., Palma, G., Tortella, G., and Fuentes, M. S. (2018). Organophosphorus pesticide mixture removal from environmental matrices by a soil Streptomyces mixed culture. Environ. Sci. Pollut. R. 25, 21296-21307. doi: 10.1007/s11356-017-9790-y

Cao, F., Souders, C. L., Li, P., Pang, S., Qiu, L., and Martyniuk, C. J. (2018). Biological impacts of organophosphates chlorpyrifos and diazinon on development, mitochondrial bioenergetics, and locomotor activity in zebrafish (Danio rerio). Neurotoxicol. Teratol. 70, 18-27. doi: 10.1016/j.ntt.2018.10.001

Carranza, C. S., Aluffi, M. E., Barberis, C. L., and Magnoli, C. E. (2016). Evaluation of chlorpyrifos tolerance and degradation by non-toxigenic Aspergillus section Flavi strains isolated from agricultural soils. Int. J. Curr. Microbiol. App. Sci. 5, 1-18. doi: 10.20546/ijcmas.2016.507.001

Casida, J. E., and Quistad, G. B. (2004). Organophosphate toxicology: safety aspects of nonacetylcholinesterase secondary targets. Chem. Res. Toxicol. 17, 983-998. doi: $10.1021 /$ tx0499259

Cederlund, H., Börjesson, E., Lundberg, D., and Stenström, J. (2016). Adsorption of pesticides with different chemical properties to a wood biochar treated with heat and iron. Water Air Soil Pollut. 227:203. doi: 10.1007/s11270-016-2894-z

Chaza, C., Sopheak, N., Mariam, H., David, D., Baghdad, O., and Moomen, B. (2018). Assessment of pesticide contamination in Akkar groundwater, northern Lebanon. Environ. Sci. Pollut. Res. Int. 25, 14302-14312. doi: 10.1007/s11356017-8568-6

Chen, S., Liu, C., Peng, C., Liu, H., Hu, M., and Zhong, G. (2012). Biodegradation of chlorpyrifos and its hydrolysis product 3,5,6-trichloro-2-pyridinol by a new fungal strain Cladosporium cladosporioides Hu-01. PLoS One 7:e47205. doi: 10.1371/journal.pone.0047205

Chen, Y., Yu, K., Hassan, M., Xu, C., Zhang, B., Gin, K. Y.-H., et al. (2018). Occurrence, distribution and risk assessment of pesticides in a river-reservoir system. Ecotoxicol. Environ. Saf. 166, 320-327. doi: 10.1016/j.ecoenv.2018.09. 107

Cheng, T. C., Harvey, S. P., and Stroup, A. N. (1993). Purification and properties of a highly active organophosphorus acid anhydrolase from Alteromonas undina. Appl. Environ. Microbiol. 59, 3138-3140. doi: 10.1128/AEM.59.9.3138-3140. 1993

Cho, K. M., Math, R. K., Islam, S. M. A., Lim, W. J., Hong, S. Y., Kim, J. M., et al. (2009). Biodegradation of chlorpyrifos by lactic acid bacteria during kimchi fermentation. J. Agric. Food. Chem. 57, 1882-1889. doi: 10.1021/jf803649z

Chu, X., Tian, J., Wu, N., and Fan, Y. (2010). An intramolecular disulfide bond is required for the thermostability of methyl parathion hydrolase, OPHC2. Appl. Microbiol. Biotechnol. 88, 125-131. doi: 10.1007/s00253-010-2738-5

Chu, Y. H., Li, Y., Wang, Y. T., Li, B., and Zhang, Y. H. (2018). Investigation of interaction modes involved in alkaline phosphatase and organophosphorus pesticides via molecular simulations. Food Chem. 254, 80-86. doi: 10.1016/j. foodchem.2018.01.187

Čolović, M. B., Vasić, V. M., Avramović, N. S., Gajić, M. M., Djurić, D. M., and Krstić, D. Z. (2015). In vitro evaluation of neurotoxicity potential and oxidative stress responses of diazinon and its degradation products in rat brain synaptosomes. Toxicol. Lett. 233, 29-37. doi: 10.1016/j.toxlet.2015.01.003

Cui, Z., Li, S., and Fu, G. (2001). Isolation of methyl parathion-degrading strain M6 and cloning of the methyl parathion hydrolase gene. Appl. Environ. Microbiol. 67, 4922-4925. doi: 10.1128/AEM.67.10.4922-4925.2001

Cycoń, M., Mrozik, A., and Piotrowska-Seget, Z. (2017). Bioaugmentation as a strategy for the remediation of pesticide-polluted soil: a review. Chemosphere 172, 52-71. doi: 10.1016/j.chemosphere.2016.12.129

Cycoń, M., Wójcik, M., and Piotrowska-Seget, Z. (2009). Biodegradation of the organophosphorus insecticide diazinon by Serratia sp. and Pseudomonas sp. and their use in bioremediation of contaminated soil. Chemosphere 76, 494-501. doi: 10.1016/j.chemosphere.2009.03.023

da Silva, N. A., Birolli, W. G., Seleghim, M. H. R., and Porto, A. L. M. (2013). Biodegradation Of The Organophosphate Pesticide Profenofos By Marine Fungi, Applied Bioremediation-Active And Passive Approaches. London: IntechOpen, doi: $10.5772 / 56372$

Daczkowski, C. M., Pegan, S. D., and Harvey, S. P. (2015). Engineering the organophosphorus acid anhydrolase enzyme for increased catalytic efficiency 
and broadened stereospecificity on Russian VX. Biochemistry 54, 6423-6433. doi: 10.1021/acs.biochem.5b00624

Daneshvar, N., Aber, S., Seyed Dorraji, M. S., Khataee, A. R., and Rasoulifard, M. H. (2007). Photocatalytic degradation of the insecticide diazinon in the presence of prepared nanocrystalline $\mathrm{ZnO}$ powders under irradiation of UV-C light. Sep. Purif. Technol. 58, 91-98. doi: 10.1016/j.seppur.2007.07.016

Dar, M. A., Kaushik, G., and Villarreal-Chiu, J. F. (2019). Pollution status and bioremediation of chlorpyrifos in environmental matrices by the application of bacterial communities: a review. J. Environ. Manage. 239, 124-136. doi: 10.1016/j.jenvman.2019.03.048

Debasmita, N., and Rajasimman, M. (2013). Optimization and kinetics studies on biodegradation of atrazine using mixed microorganisms. Alex. Eng. J. 52, 499-505. doi: 10.1016/j.aej.2013.06.008

Dehghani, M. H., Kamalian, S., Shayeghi, M., Yousefi, M., Heidarinejad, Z., and Agarwal, S. (2019). High-performance removal of diazinon pesticide from water using multi-walled carbon nanotubes. Microchem. J. 145, 486-491. doi: 10.1016/ j.microc.2018.10.053

Deng, S., Chen, Y., Wang, D., Shi, T., Wu, X., and Ma, X. (2015). Rapid biodegradation of organophosphorus pesticides by Stenotrophomonas sp G1. J. Hazard. Mater. 297, 17-24. doi: 10.1016/j.jhazmat.2015.04.052

Derylo-Marczewska, A., Blachnio, M., Marczewski, A. W., Swiatkowski, A., and Buczek, B. (2017). Adsorption of chlorophenoxy pesticides on activated carbon with gradually removed external particle layers. Chem. Eng. J. 308, 408-418. doi: 10.1016/j.cej.2016.09.082

Díaz-Resendiz, K. J. G., Ortiz-Lazareno, P. C., Covantes-Rosales, C. E., TrujilloLepe, A. M., Toledo-Ibarra, G. A., and Ventura-Ramón, G. H. (2019). Effect of diazinon, an organophosphate pesticide, on signal transduction and death induction in mononuclear cells of Nile tilapia fish (Oreochromis niloticus). Fish Shellfish Immun. 89, 12-17. doi: 10.1016/j.fsi.2019.03.036

Ding, Y., Liu, Y., Liu, S., Huang, X., Li, Z., Tan, X., et al. (2017). Potential benefits of biochar in agricultural soils: a review. Pedosphere 27, 645-661. doi: 10.1016/ S1002-0160(17)60375-8

Dong, Y. J., Bartlam, M., Sun, L., Zhou, Y. F., Zhang, Z. P., Zhang, C. G., et al. (2005). Crystal structure of methyl parathion hydrolase from Pseudomonas sp. WBC-3. J. Mol. Biol. 353, 655-663. doi: 10.1016/j.jmb.2005.08.057

Draganov, D. I., and La Du, B. N. (2004). Pharmacogenetics of paraoxonases: a brief review. Naunyn Schmiedebergs Arch. Pharmacol. 369, 78-88. doi: 10.1007/ s00210-003-0833-1

Draganov, D. I., Teiber, J. F., Speelman, A., Osawa, Y., Sunahara, R., and La Du, B. N. (2005). Human paraoxonases (PON1, PON2, and PON3) are lactonases with overlapping and distinct substrate specificities. J. Lipid. Res. 46, 1239-1247. doi: 10.1194/jlr.M400511-JLR200

Dumas, D. P., Caldwell, S. R., Wild, J. R., and Raushel, F. M. (1989). Purification and properties of the phosphotriesterase from Pseudomonas diminuta. J. Biol. Chem. 264, 19659-19665. doi: 10.1016/S0021-9258(19)47164-0

Durán, E., Bueno, S., Hermosín, M. C., Cox, L., and Gámiz, B. (2019). Optimizing a low added value bentonite as adsorbent material to remove pesticides from water. Sci. Total Environ. 672, 743-751. doi: 10.1016/j.scitotenv.2019.04.014

Dzionek, A., Wojcieszyńska, D., and Guzik, U. (2016). Natural carriers in bioremediation: a review. Electron. J. Biotechn. 23, 3. doi: 10.1016/j.ejbt.2016. 07.003

Ehrampoush, M. H., Sadeghi, A., Ghaneian, M. T., and Bonyadi, Z. (2017). Optimization of diazinon biodegradation from aqueous solutions by Saccharomyces cerevisiae using response surface methodology. AMB Express 7:68. doi: 10.1186/s13568-017-0366-5

El Hassani, K., Kalnina, D., Turks, M., Beakou, B. H., and Anouar, A. (2019). Enhanced degradation of an azo dye by catalytic ozonation over Ni-containing layered double hydroxide nanocatalyst. Sep. Purif. Technol. 210, 764-774. doi: 10.1016/j.seppur.2018.08.074

Elias, M., Dupuy, J., Merone, L., Mandrich, L., Porzio, E., Moniot, S., et al. (2008). Structural basis for natural lactonase and promiscuous phosphotriesterase activities. J. Mol. Biol. 379, 1017-1028. doi: 10.1016/j.jmb.2008.04.022

Emam, H. E., and Shaheen, T. I. (2019). Investigation into the role of surface modification of cellulose nanocrystals with succinic anhydride in dye removal. J. Polym. Environ. 27, 2419-2427. doi: 10.1007/s10924-019-01533-9

Fadaei, A., Dehghani, M. H., Nasseri, S., Mahvi, A. H., Rastkari, N., and Shayeghi, M. (2012). Organophosphorous pesticides in surface water of Iran. B. Environ. Contam. Tox. 88, 867-869. doi: 10.1007/s00128-012-0568-0
Fareed, R., Ansari, A., Seecharran, D., and Munroe, L. (2017). Investigating the degrading properties of three different strains of fungi on commonly used pesticides in Guyana. Biofarmasi J. Nat. Prod. Biochem. 15, 5-14. doi: 10.13057/ biofar/f150102

Fuentes, M. S., Saez, M. J., Benimeli, C. S., and Amoroso, M. J. (2011). Lindane biodegradation by defined consortia of indigenous Streptomyces strains. Water Air Soil Pollut 222, 217-223. doi: 10.1007/s11270-011-0818-5

Gao, B., Bian, X., Chi, L., Tu, P., Ru, H., and Lu, K. (2017). Organophosphate diazinon altered quorum sensing, cell motility, stress response, and carbohydrate metabolism of gut microbiome. Toxicol. Sci. 157, 354-364. doi: $10.1093 /$ toxsci/kfx053

Gao, Y., Chen, S., Hu, M., Hu, Q., Luo, J., and Li, Y. (2012). Purification and characterization of a novel chlorpyrifos hydrolase from Cladosporium cladosporioides Hu-01. PLoS One 7:e38137. doi: 10.1371/journal.pone.0038137

Ghanem, E., and Raushel, F. (2005). Detoxification of organophosphate nerve agents by bacterial phosphotriesterase. Toxicol. Appl. Pharm. 207, 459-470. doi: 10.1016/j.taap.2005.02.025

Ghetti, F. F. (2018). Influence of gut microbiota on the development and progression of nonalcoholic steatohepatitis. Eur. J. Nutr 16, 861-876. doi: 10. 1007/s00394-017-1524-x

Gillois, K., Lévêque, M., Théodorou, V., Robert, H., and Mercier-Bonin, M. (2018). Mucus: an underestimated gut target for environmental pollutants and food additives. Microorganisms 6:53. doi: 10.3390/microorganisms6020053

Glavan, G., Kos, M., Božič, J., Drobne, D., Sabotič, J., and Kokalj, A. J. (2018). Different response of acetylcholinesterases in salt- and detergentsoluble fractions of honeybee haemolymph, head and thorax after exposure to diazinon. Comp. Biochem. Phys. C. 205, 8-14. doi: 10.1016/j.cbpc.2017. 12.004

Glinski, D. A., Purucker, S. T., Van Meter, R. J., Black, M. C., and Henderson, W. M. (2018). Analysis of pesticides in surface water, stemflow, and throughfall in an agricultural area in South Georgia. USA. Chemosphere 209, 496-507. doi: 10.1016/j.chemosphere.2018.06.116

Góngora-Echeverría, V. R., García-Escalante, R., Rojas-Herrera, R., GiácomanVallejos, G., and Ponce-Caballero, C. (2020). Pesticide bioremediation in liquid media using a microbial consortium and bacteria-pure strains isolated from a biomixture used in agricultural areas. Ecotoxicol. Environ. Saf. 200:110734. doi: 10.1016/j.ecoenv.2020.110734

Gotthard, G., Hiblot, J., Gonzalez, D., Elias, M., and Chabriere, E. (2013). Structural and enzymatic characterization of the phosphotriesterase OPHC2 from Pseudomonas pseudoalcaligenes. PLoS One 8:e77995. doi: 10.1371/journal. pone. 0077995

Graham, S. C., Bond, C. S., Freeman, H. C., and Guss, J. M. (2005). Structural and functional implications of metal ion selection in aminopeptidase $\mathrm{P}$, a metalloprotease with a dinuclear metal center. Biochemistry 44, 13820-13836. doi: 10.1021/bi0512849

Groh, K. J. (2017). Food contact materials and gut health: implications for toxicity assessment and relevance of high molecular weight migrants. Food Chem. Toxicol. 109, 1-18. doi: 10.1016/j.fct.2017.08.023

Hajirezaee, S., Mirvaghefi, A., Farahmand, H., and Agh, N. (2017). NMR-based metabolomic study on the toxicological effects of pesticide, diazinon on adaptation to sea water by endangered Persian sturgeon, Acipenser persicus fingerlings. Chemosphere 185, 213-226. doi: 10.1016/j.chemosphere.2017.07. 016

Hamad, M. T. M. H. (2020). Biodegradation of diazinon by fungal strain Apergillus niger MK640786 using response surface methodology. Environ. Technol. Inno. 18:100691. doi: 10.1016/j.eti.2020.100691

Hassan, A. F., Elhadidy, H., and Abdel-Mohsen, A. M. (2017). Adsorption and photocatalytic detoxification of diazinon using iron and nanotitania modified activated carbons. J. Taiwan Inst. Chem. E. 75, 299-306. doi: 10.1016/j.jtice. 2017.03.026

Hassanshahian, M. (2016). Isolation and characterization of diazinon degrading bacteria from contaminated agriculture soils. Iran. J. Toxicol. 10, 13-20.

Hossaini, H., Moussavi, G., and Farrokhi, M. (2017). Oxidation of diazinon in cns-ZnO/LED photocatalytic process: catalyst preparation, photocatalytic examination, and toxicity bioassay of oxidation by-products. Sep. Purif. Technol. 174, 320-330. doi: 10.1016/j.seppur.2016.11.005

Huang, Y., Lin, Z., Zhang, W., Pang, S., Bhatt, P., Rene, E. R., et al. (2020). New insights into the microbial degradation of D-cyphenothrin in 
contaminated water/soil environments. Microorganisms 8:473. doi: 10.3390/ microorganisms 8040473

Huang, Y., Zhang, W., Pang, S., Chen, J., Bhatt, P., Mishra, S., et al. (2021). Insights into the microbial degradation and catalytic mechanisms of chlorpyrifos. Environ. Res. 194:110660. doi: 10.1016/j.envres.2020.110660

Idris, E. E., Iglesias, D. J., Talon, M., and Borriss, R. (2007). Tryptophan-dependent production of indole-3-acetic acid (IAA) affects level of plant growth promotion by Bacillus amyloliquefaciens FZB42. Mol. Plant. Microbe Interact. 20, 619-626. doi: 10.1094/MPMI-20-6-0619

Islam, S. M. A., Math, R. K., Cho, K. M., Lim, W. J., Hong, S. Y., Kim, J. M., et al. (2010). Organophosphorus hydrolase (OpdB) of Lactobacillus brevis WCP902 from kimchi is able to degrade organophosphorus pesticides. J. Agric. Food Chem. 58, 5380-5386. doi: 10.1021/jf903878e

Jacquet, P., Daudé, D., Bzdrenga, J., Masson, P., Elias, M., and Chabrière, E. (2016). Current and emerging strategies for organophosphate decontamination: special focus on hyperstable enzymes. Environ. Sci. Pollut. R. 23, 8200-8218. doi: 10.1007/s11356-016-6143-1

Jonidi-Jafari, A., Shirzad-Siboni, M., Yang, J.-K., Naimi-Joubani, M., and Farrokhi, M. (2015). Photocatalytic degradation of diazinon with illuminated $\mathrm{ZnO}-\mathrm{TiO} 2$ composite. J. Taiwan Inst. Chem. E. 50, 100-107. doi: 10.1016/j.jtice.2014.12. 020

Kapoor, M., and Rajagopal, R. (2011). Enzymatic bioremediation of organophosphorus insecticides by recombinant organophosphorous hydrolase. Int. Biodeter. Biodegr. 65, 896-901. doi: 10.1016/j.ibiod.2010.12.017

Khoiriah, K., Wellia, D. V., Gunlazuardi, J., and Safni, S. (2020). Photocatalytic degradation of commercial diazinon pesticide using C,N-codoped $\mathrm{TiO} 2$ as photocatalyst. Indones. J. Chem. 20, 587-596. doi: 10.22146/ijc.43982

Kumar, S., Kaushik, G., Dar, M. A., Nimesh, S., López-Chuken, U. J., and VillarrealChiu, J. F. (2018). Microbial degradation of organophosphate pesticides: a review. Pedosphere 28, 190-208. doi: 10.1016/S1002-0160(18)60017-7

Li, J., Zhang, W., Lin, Z., Huang, Y., Bhatt, P., and Chen, S. (2021). Emerging strategies for the bioremediation of the phenylurea herbicide (PUH) diuron. Front. Microbiol. 12:686509. doi: 10.3389/fmicb.2021.686509

Li, W., Liu, Y., Duan, J., Leeuwen, J., and Saint, C. P. (2015). UV and UV/H2O2 treatment of diazinon and its influence on disinfection byproduct formation following chlorination. Chem. Eng. J. 274, 39-49. doi: 10.1016/j.cej.2015.03.130

Liang, Y., Zhan, J., Liu, D., Luo, M., Han, J., Liu, X., et al. (2019). Organophosphorus pesticide chlorpyrifos intake promotes obesity and insulin resistance through impacting gut and gut microbiota. Microbiome 7:19. doi: 10.1186/s40168-019-0635-4

Lin, Z., Pang, S., Zhang, W., Mishra, S., Bhatt, P., and Chen, S. (2020). Degradation of acephate and its intermediate methamidophos: mechanisms and biochemical pathways. Front. Microbiol. 11:2045. doi: 10.3389/fmicb.2020.02045

Lin, Z., Pang, S., Zhou, Z., Wu, X., Bhatt, P., and Chen, S. (2021). Current insights into the microbial degradation for butachlor: strains, metabolic pathways, and molecular mechanisms. Appl. Microbiol. Biotechnol. 105, 4369-4381. doi: 10. 1007/s00253-021-11346-3

Liu, F., Hong, M., Liu, D., Li, Y., Shou, P., Yan, H., et al. (2007). Biodegradation of methyl parathion by Acinetobacter radioresistens USTB-04. J. Environ. Sci. 19, 1257-1260. doi: 10.1016/s1001-0742(07)60205-8

Liu, H., Zhang, J. J., Wang, S. J., Zhang, X. E., and Zhou, N. Y. (2005). Plasmidborne catabolism of methyl parathion and p-nitrophenol in Pseudomonas sp. strain WBC-3. Biochem. Biophys. Res. Commun. 334, 1107-1114. doi: 10.1016/ j.bbrc.2005.07.006

Liu, N., Charrua, A. B., Weng, C. H., Yuan, X., and Ding, F. (2015). Characterization of biochars derived from agriculture wastes and their adsorptive removal of atrazine from aqueous solution: a comparative study. Bioresour. Technol. 198, 55-62. doi: 10.1016/j.biortech.2015.08.129

Liu, Y., Liu, J., Lin, Y., Zhang, Y., and Wei, Y. (2009). Simple fabrication and photocatalytic activity of S-doped $\mathrm{TiO} 2$ under low power LED visible light irradiation. Ceram. Int. 35, 3061-3065. doi: 10.1016/j.ceramint.2009.04.021

Lu, P., Li, Q., Liu, H., Feng, Z., Yan, X., Hong, Q., et al. (2013). Biodegradation of chlorpyrifos and 3,5,6-trichloro-2-pyridinol by Cupriavidus sp. DT-1. Bioresour. Technol. 127, 337-342. doi: 10.1016/j.biortech.2012.09.116

Mahiudddin, M., Fakhruddin, A. N. M., Chowdhury, M., Rahman, M., and Alam, M. (2014). Degradation of the organophosphorus insecticide diazinon by soil bacterial isolate. Int. J. Biotech. 7, 12-23.
Malakootian, M., Shahamat, Y. D., and Mahdizadeh, H. (2020). Purification of diazinon pesticide by sequencing batch moving-bed biofilm reactor after ozonation/Mg-Al layered double hydroxides pre-treated effluent. Sep. Purif. Technol. 242, 116754. doi: 10.1016/j.seppur.2020.116754

Maleki, A., Moradi, F., Shahmoradi, B., Rezaee, R., and Lee, S.-M. (2020). The photocatalytic removal of diazinon from aqueous solutions using tungsten oxide doped zinc oxide nanoparticles immobilized on glass substrate. J. Mol. Liq. 297:111918. doi: 10.1016/j.molliq.2019.111918

Mandal, A., Singh, N., and Purakayastha, T. J. (2017). Characterization of pesticide sorption behaviour of slow pyrolysis biochars as low cost adsorbent for atrazine and imidacloprid removal. Sci. Total Environ. 577, 376-385. doi: 10.1016/j. scitotenv.2016.10.204

Mena, F., González-Ortegón, E., Solano, K., and Araújo, C. V. M. (2020). The effect of the insecticide diazinon on the osmoregulation and the avoidance response of the white leg shrimp (Penaeus vannamei) is salinity dependent. Ecotoxicol. Environ. Saf. 206:111364. doi: 10.1016/j.ecoenv.2020.111364

Meng, D., Jiang, W., Li, J., Huang, L., Zhai, L., Zhang, L., et al. (2019). An alkaline phosphatase from Bacillus amyloliquefaciens YP6 of new application in biodegradation of five broad-spectrum organophosphorus pesticides. J. Environ. Sci. Health B. 54, 336-343. doi: 10.1080/03601234.2019.1571363

Mirmasoomi, S. R., Mehdipour Ghazi, M., and Galedari, M. (2017). Photocatalytic degradation of diazinon under visible light using $\mathrm{TiO} 2 / \mathrm{Fe} 2 \mathrm{O} 3$ nanocomposite synthesized by ultrasonic-assisted impregnation method. Sep. Purif. Technol. 175, 418-427. doi: 10.1016/j.seppur.2016.11.021

Mishra, S., Pang, S., Zhang, W., Lin, Z., Bhatt, P., and Chen, S. (2021). Insights into the microbial degradation and biochemical mechanisms of carbamates. Chemosphere 279:130500. doi: 10.1016/j.chemosphere.2021.130500

Mishra, S., Zhang, W., Lin, Z., Pang, S., Huang, Y., Bhatt, P., et al. (2020). Carbofuran toxicity and its microbial degradation in contaminated environments. Chemosphere 259:127429. doi: 10.1016/j.chemosphere.2020. 127419

Mitra, A., and Maitra, S. K. (2018). Reproductive toxicity of organophosphate pesticides. Ann. Clin. Lab. Sci. 1, 2-22.

Mohagheghian, A., Karimi, S.-A., Yang, J. K., and Shirzad-Siboni, M. (2016). Photocatalytic degradation of diazinon by illuminated WO3 nanopowder. Desalin. Water Treat. 57, 8262-8269. doi: 10.1080/19443994.2015.1017009

Montuori, P., Aurino, S., Garzonio, F., Sarnacchiaro, P., Polichetti, S., and Nardone, A. (2016). Estimates of Tiber River organophosphate pesticide loads to the Tyrrhenian Sea and ecological risk. Sci. Total Environ. 559, 218-231. doi: 10. 1016/j.scitotenv.2016.03.156

Mulbry, W. W., and Karns, J. S. (1989). Parathion hydrolase specified by the Flavobacterium opd gene: relationship between the gene and protein. J. Bacteriol. 171, 6740-6746.

Mulla, S. I., Hu, A., Sun, Q., Li, J., Suanon, F., Ashfaq, M., et al. (2018). Biodegradation of sulfamethoxazole in bacteria from three different origins. J. Environ. Manage. 206, 93-102. doi: 10.1016/j.jenvman.2017.10.029

Nakaoka, Y., Katsumata, H., Kaneco, S., Suzuki, T., and Ohta, K. (2010). Photocatalytic degradation of diazinon in aqueous solution by platinized $\mathrm{TiO} 2$. Desalin. Water Treat. 13, 427-436. doi: 10.5004/dwt.2010.1000

Nasrollahi, M., Pourbabaei, A. A., Etesami, H., and Talebi, K. (2020). Diazinon degradation by bacterial endophytes in rice plant (Oryzia sativa L.): a possible reason for reducing the efficiency of diazinon in the control of the rice stemborer. Chemosphere 246:125759. doi: 10.1016/j.chemosphere.2019.125759

Okoli, U., Nubila, N., and Okafor, M. (2017). Organophosphorous pesticide: an environmental pollutant perspective. J. Chem. Phar. Res. 9:117.

Okoya, A. A., Adegbaju, O. S., Akinola, O. E., Akinyele, A. B., and Amuda, O. S. (2020). Comparative assessment of the efficiency of rice husk biochar and conventional water treatment method to remove chlorpyrifos from pesticide polluted water. Cur. J. Appl. Sci. Technol. 39, 1-11. doi: 10.9734/cjast/2020/ v39i230491

Orbulescu, J., Constantine, C. A., Rastogi, V. K., Shah, S. S., DeFrank, J. J., and Leblanc, R. M. (2006). Detection of organophosphorus compounds by covalently immobilized organophosphorus hydrolase. Anal. Chem. 78, 70167021. doi: 10.1021/ac061118m

Orge, C. A., Faria, J. L., and Pereira, M. F. R. (2017). Photocatalytic ozonation of aniline with TiO2-carbon composite materials. J. Environ. Manage. 195, 208-215. doi: 10.1016/j.jenvman.2016.07.091 
Palma, P., Köck-Schulmeyer, M., Alvarenga, P., Ledo, L., Barbosa, I. R., and Alda, M. (2014). Risk assessment of pesticides detected in surface water of the Alqueva reservoir (Guadiana basin, southern of Portugal). Sci. Total Environ. 488-489, 208-219. doi: 10.1016/j.scitotenv.2014.04.088

Pedroso, M. M., Ely, F., Mitić, N., Carpenter, M. C., Gahan, L. R., Wilcox, D. E., et al. (2014). Comparative investigation of the reaction mechanisms of the organophosphate-degrading phosphotriesterases from Agrobacterium radiobacter (OpdA) and Pseudomonas diminuta (OPH). J. Biol. Inorg. Chem. 19, 1263-1275. doi: 10.1007/s00775-014-1183-9

Philippe, V., Neveen, A., Marwa, A., and Ahmad Basel, A.-Y. (2021). Occurrence of pesticide residues in fruits and vegetables for the Eastern Mediterranean Region and potential impact on public health. Food Control 119:107457. doi: 10.1016/j.foodcont.2020.107457

Phuong, N. M., Chu, N. C., Van Thuan, D., Ha, M. N., Hanh, N. T., and Viet, H. D. T. (2019). Novel removal of diazinon pesticide by adsorption and photocatalytic degradation of visible light-driven Fe-TiO2/Bent-Fe photocatalyst. J. Chem. 2019, 1-7. doi: 10.1155/2019/2678927

Pirsaheb, M., Dargahi, A., Hazrati, S., and Fazlzadehdavil, M. (2014). Removal of diazinon and 2,4-dichlorophenoxyacetic acid (2,4-D) from aqueous solutions by granular-activated carbon. Desalin. Water Treat. 52, 4350-4355. doi: 10. 1080/19443994.2013.801787

Pirsaheb, M., Fattahi, N., Rahimi, R., Sharafi, K., and Ghaffari, H. R. (2017). Evaluation of abamectin, diazinon and chlorpyrifos pesticide residues in apple product of Mahabad region gardens: Iran in 2014. Food Chem. 231, 148-155. doi: 10.1016/j.foodchem.2017.03.120

Ponnam, V., Katari, N. K., Mandapati, R. N., Nannapaneni, S., Tondepu, S., and Jonnalagadda, S. B. (2020). Efficacy of biochar in removal of organic pesticide, Bentazone from watershed systems. J. Environ. Sci. Heal. B. 55, 396-405. doi: 10.1080/03601234.2019.1707008

Pordel, M. A., Maleki, A., Ghanbari, R., Rezaee, R., Khamforoush, M., and Daraei, H. (2019). Evaluation of the effect of electrospun nanofibrous membrane on removal of diazinon from aqueous solutions. React. Funct. Polym. 139, 85-91. doi: 10.1016/j.reactfunctpolym.2019.03.017

Pourbabaee, A. A., Soleymani, S., Farahbakhsh, M., and Torabi, E. (2018). Biodegradation of diazinon by the Stenotrophomonas maltophilia PS: pesticide dissipation kinetics and breakdown characterization using FTIR. Int. J. Environ. Sci. Technol. 15, 1073-1084. doi: 10.1007/s13762-017-1452-6

Qiu, J., Zhang, Y., Zhao, L., He, Q., Jiang, J., Hong, Q., et al. (2018). Isolation and characterization of the cotinine-degrading bacterium Nocardioides sp. strain JQ2195. J. Hazard. Mater. 353, 158-165. doi: 10.1016/j.jhazmat.2018.04.003

Ramadevi, C., Nath, M. M., and Prasad, M. G. (2012). Mycodegradation of malathion by a soil fungal isolate, Aspergillus niger. Int. J. Basic. Appl. Chem. Sci. 2, 108-115.

Rezaei, S. S., Dehghanifard, E., Noorisepehr, M., Ghadirinejad, K., Kakavandi, B., and Esfahani, A. R. (2019). Efficient clean-up of waters contaminated with diazinon pesticide using photo-decomposition of peroxymonosulfate by $\mathrm{ZnO}$ decorated on a magnetic core/shell structure. J. Environ. Manage 250:109472. doi: 10.1016/j.jenvman.2019.109472

Roman, P., Cardona, D., Sempere, L., and Carvajal, F. (2019). Microbiota and organophosphates. Neurotoxicology 75, 200-208. doi: 10.1016/j.neuro.2019.09. 013

Roselló-Márquez, G., Fernández-Domene, R. M., Sánchez-Tovar, R., CifreHerrando, M., and García-Antón, J. (2021). Degradation of Diazinon based on photoelectrocatalytic technique using enhanced WO3 nanostructures: mechanism and pathway. J. Environ. Chem. Eng. 9:105371. doi: 10.1016/j.jece. 2021.105371

Sajjad, A. K. L., Sajjad, S., Iqbal, A., and Ryma, N. A. (2018). ZnO/WO3 nanostructure as an efficient visible light catalyst. Ceramics Int. 44, 9364-9371. doi: 10.1016/j.ceramint.2018.02.150

Sajjadi, S., Khataee, A., Bagheri, N., Kobya, M., Şenocak, A., and Demirbas, E. (2019). Degradation of diazinon pesticide using catalyzed persulfate with Fe3O4@MOF-2 nanocomposite under ultrasound irradiation. J. Ind. Eng. Chem. 77, 280-290. doi: 10.1016/j.jiec.2019.04.049

Saleh, I. A., Zouari, N., and Al-Ghouti, M. A. (2020). Removal of pesticides from water and wastewater: chemical, physical and biological treatment approaches. Environ. Technol. Inno. 19:101026. doi: 10.1016/j.eti.2020. 101026
Sarathy, S., and Mohseni, M. (2010). Effects of UV/H2O2 advanced oxidation on chemical characteristics and chlorine reactivity of surface water natural organic matter. Water Res. 44, 4087-4096. doi: 10.1016/j.watres.2010.05.025

Scharff, E. I., Koepke, J., Fritzsch, G., Lücke, C., and Rüterjans, H. (2001). Crystal structure of diisopropylfluorophosphatase from Loligo vulgaris. Structure 9, 493-502. doi: 10.1016/s0969-2126(01)00610-4

Seo, J. S., Keum, Y. S., Harada, R. M., and Li, Q. X. (2007). Isolation and characterization of bacteria capable of degrading polycyclic aromatic hydrocarbons (PAHs) and organophosphorus pesticides from PAHcontaminated soil in Hilo. J. Agric. Food Chem. 55, 5383-5389. doi: $10.1021 /$ jf0637630

Sethunathan, N., and Yoshida, T. (1973). A Flavobacterium sp. that degrades diazinon and parathion. Can. J. Microbiol. 19, 873-875. doi: 10.1139/m73-138

Shah, P. C., Kumar, V. R., Dastager, S. G., and Khire, J. M. (2017). Phytase production by Aspergillus niger NCIM 563 for a novel application to degrade organophosphorus pesticides. AMB Express 7:66. doi: 10.1186/s13568-0170370-9

Sharma, A., Kumar, V., Shahzad, B., Tanveer, M., Sidhu, G. P. S., Handa, N., et al. (2019). Worldwide pesticide usage and its impacts on ecosystem. SN Appl. Sci. 1:1446. doi: 10.1007/s42452-019-1485- 1

Shemer, H., and Linden, K. (2006). Degradation and by-product formation of diazinon in water during $\mathrm{UV}$ and $\mathrm{UV} / \mathrm{H} 2 \mathrm{O} 2$ treatment. J. Hazard. Mater. 136, 553-559. doi: 10.1016/j.jhazmat.2005.12.028

Shirzad-Siboni, M., Jonidi-Jafari, A., Farzadkia, M., Esrafili, A., and Gholami, M. (2017). Enhancement of photocatalytic activity of $\mathrm{Cu}$-doped $\mathrm{ZnO}$ nanorods for the degradation of an insecticide: kinetics and reaction pathways. J. Environ. Manage. 186, 1-11. doi: 10.1016/j.jenvman.2016.10.049

Shrestha, S., Parks, C. G., Goldner, W. S., Kamel, F., Umbach, D. M., and Ward, M. H. (2018). Incident thyroid disease in female spouses of private pesticide applicators. Environ. Int. 118, 282-292. doi: 10.1016/j.envint.2018.05.041

Sikakwe, G. U., Nwachukwu, A. N., Uwa, C. U., and Abam, E. G. (2020). Geochemical data handling, using multivariate statistical methods for environmental monitoring and pollution studies. Environ. Technol. Inno. 18:100645. doi: 10.1016/j.eti.2020.100645

Singh, B., Walker, A., Morgan, J., and Wright, D. (2004). Biodegradation of chlorpyrifos by Enterobacter strain B-14 and its use in bioremediation of contaminated soils. Appl. Environ. Microbiol. 70, 4855-4863. doi: 10.1128/ AEM.70.8.4855-4863.2004

Sogorb, M. A., and Vilanova, E. (2002). Enzymes involved in the detoxification of organophosphorus, carbamate and pyrethroid insecticides through hydrolysis. Toxicol. Lett. 128, 215-228. doi: 10.1016/S0378-4274(01)00543-4

Sogorb, M. A., Vilanova, E., and Carrera, V. (2004). Future applications of phosphotriesterases in the prophylaxis and treatment of organophosporus insecticide and nerve agent poisonings. Toxicol. Lett. 151, 219-233. doi: 10. 1016/j.toxlet.2004.01.022

Soto-Vázquez, L., Cotto, M., Ducongé, J., Morant, C., and Márquez, F. (2016). Synthesis and photocatalytic activity of $\mathrm{TiO} 2$ nanowires in the degradation of p-aminobenzoic acid: a comparative study with a commercial catalyst. J. Environ. Manage. 167, 23-28. doi: 10.1016/j.jenvman.2015.11.006

Sultatos, L. G. (2006). "Chapter 15-interactions of organophosphorus and carbamate compounds with cholinesterases," in Toxicology of Organophosphate \& Carbamate Compounds, ed. R. C. Gupta (Burlington, MA: Academic Press), 209-218. doi: 10.1016/B978-012088523-7/50016-8

Sumon, K. A., Rashid, H., Peeters, E. T. H. M., Bosma, R. H., and Brink, P. J. (2018). Environmental monitoring and risk assessment of organophosphate pesticides in aquatic ecosystems of north-west Bangladesh. Chemosphere 206, 92-100. doi: 10.1016/j.chemosphere.2018.04.167

Suo, F., You, X., Ma, Y., and Li, Y. (2019). Rapid removal of triazine pesticides by $\mathrm{P}$ doped biochar and the adsorption mechanism. Chemosphere 235, 918-925. doi: 10.1016/j.chemosphere.2019.06.158

Tabasideh, S., Maleki, A., Shahmoradi, B., Ghahremani, E., and McKay, G. (2017). Sonophotocatalytic degradation of diazinon in aqueous solution using irondoped TiO2 nanoparticles. Sep. Purif. Technol. 189, 186-192. doi: 10.1016/j. seppur.2017.07.065

Thakur, M., Medintz, I. L., and Walper, S. A. (2019). Enzymatic bioremediation of organophosphate compounds-progress and remaining challenges. Front. Bioeng. Biotech. 7:289. doi: 10.3389/fbioe.2019.00289 
Toledo-Ibarra, G. A., Díaz-Resendiz, K. J. G., Pavón-Romero, L., Rojas-García, A. E., Medina-Díaz, I. M., and Girón-Pérez, M. I. (2016). Effects of diazinon on the lymphocytic cholinergic system of Nile tilapia fish (Oreochromis niloticus). Vet. Immunol. Immunop. 176, 58-63. doi: 10.1016/j.vetimm.2016.05.010

Toolabi, A., Malakootian, M., Ghaneian, M. T., Esrafili, A., Ehrampoush, M. H., AskarShahi, M., et al. (2018). Modeling photocatalytic degradation of diazinon from aqueous solutions and effluent toxicity risk assessment using Escherichia coli LMG 15862. AMB Express 8:59. doi: 10.1186/s13568-018-0589-0

Tran, H. N., Tomul, F., Thi Hoang Ha, N., Nguyen, D. T., Lima, E. C., and Le, G. T. (2020). Innovative spherical biochar for pharmaceutical removal from water: insight into adsorption mechanism. J. Hazard. Mater. 394:122255. doi: 10.1016/j.jhazmat.2020.122255

Triassi, M., Nardone, A., Giovinetti, M. C., De Rosa, E., Canzanella, S., and Sarnacchiaro, P. (2019). Ecological risk and estimates of organophosphate pesticides loads into the Central Mediterranean Sea from Volturno River, the river of the "Land of Fires" area, southern Italy. Sci. Total Environ. 678, 741-754. doi: 10.1016/j.scitotenv.2019.04.202

Velki, M., Di Paolo, C., Nelles, J., Seiler, T.-B., and Hollert, H. (2017). Diuron and diazinon alter the behavior of zebrafish embryos and larvae in the absence of acute toxicity. Chemosphere 180, 65-76. doi: 10.1016/j.chemosphere.2017.04. 017

Velmurugan, G., Ramprasath, T., Swaminathan, K., Mithieux, G., Rajendhran, J., and Dhivakar, M. (2017). Gut microbial degradation of organophosphate insecticides-induces glucose intolerance via gluconeogenesis. Genome Biol. 18:8. doi: 10.1186/s13059-016-1134-6

Vera, M., Nyanhongo, G. S., Guebitz, G. M., and Rivas, B. L. (2020). Polymeric microspheres as support to co-immobilized Agaricus bisporus and Trametes versicolor laccases and their application in diazinon degradation. Arab. J. Chem. 13, 4218-4227. doi: 10.1016/j.arabjc.2019.07.003

Villiot, A., Chrétien, E., Drab-Sommesous, E., Rivière, E., Chakir, A., and Roth, E. (2018). Temporal and seasonal variation of atmospheric concentrations of currently used pesticides in Champagne in the centre of Reims from 2012 to 2015. Atmos. Environ. 174, 82-91. doi: 10.1016/j.atmosenv.2017.11.046

Vyas, N. K., Nickitenko, A., Rastogi, V. K., Shah, S. S., and Quiocho, F. A. (2010). Structural insights into the dual activities of the nerve agent degrading organophosphate anhydrolase/prolidase. Biochemistry 49, 547-559. doi: 10. 1021/bi9011989

Wang, G., and Liu, Y. (2016). Diazinon degradation by a novel strain Ralstonia sp. DI-3 and X-ray crystal structure determination of the metabolite of diazinon. J. Biosciences 41, 359-366. doi: 10.1007/s12038-016-9619-8

Wee, S. Y., Omar, T. F. T., Aris, A. Z., and Lee, Y. (2016). Surface water organophosphorus pesticides concentration and distribution in the Langat River, Selangor, Malaysia. Expos. Health 8, 497-511. doi: 10.1007/s12403-0160214-x

Wheelock, C. E., Phillips, B. M., Anderson, B. S., Miller, J. L., Miller, M. J., and Hammock, B. D. (2008). Applications of carboxylesterase activity in environmental monitoring and toxicity identification evaluations (TIEs). Rev. Environ. Contam. Toxicol. 195, 117-178. doi: 10.1007/978-0-387-77030-7_5

Wheelock, C. E., Shan, G., and Ottea, J. (2005). Overview of carboxylesterases and their role in the metabolism of insecticides. J. Pestic. Sci. 30, 75-83. doi: 10.1584/jpestics.30.75

Wols, B. A., and Hofman-Caris, C. H. M. (2012). Review of photochemical reaction constants of organic micropollutants required for UV advanced oxidation processes in water. Water Res. 46, 2815-2827. doi: 10.1016/j.watres.2012.03.036
Wu, J., Yang, J., Feng, P., Huang, G., Xu, C., and Lin, B. (2020). Highefficiency removal of dyes from wastewater by fully recycling litchi peel biochar. Chemosphere 246:125734. doi: 10.1016/j.chemosphere.2019.1 25734

Yamamoto, K., and Yamada, N. (2016). Identification of a diazinon-metabolizing glutathione S-transferase in the silkworm Bombyx mori. Sci. Rep. 6:30073. doi: 10.1038/srep30073

Yang, L., Zhao, Y., Zhang, B., Yang, C.-H., and Zhang, X. (2005). Isolation and characterization of a chlorpyrifos and 3,5,6-trichloro-2-pyridinol degrading bacterium. FEMS Microbiol. Lett. 251, 67-73. doi: 10.1016/j.femsle.2005.07.031

Yen, J., Donerly, S., Levin, E. D., and Linney, E. A. (2011). Differential acetylcholinesterase inhibition of chlorpyrifos, diazinon and parathion in larval zebrafish. Neurotoxicol. Teratol. 33, 735-741. doi: 10.1016/j.ntt.2011.10.004

Zainuddin, A. H., Wee, S. Y., and Aris, A. Z. (2020). Occurrence and potential risk of organophosphorus pesticides in urbanised Linggi River, Negeri Sembilan, Malaysia. Environ. Geochem. Hlth. 42, 3703-3715. doi: 10.1007/s10653-02000604-4

Zhan, H., Wang, H., Liao, L., Feng, Y., Fan, X., Zhang, L., et al. (2018b). Kinetics and novel degradation pathway of permethrin in Acinetobacter baumannii $\mathrm{ZH}-14$. Front. Microbiol. 9:98. doi: 10.3389/fmicb.2018.00098

Zhan, H., Feng, Y., Fan, X., and Chen, S. (2018a). Recent advances in glyphosate biodegradation. Appl. Microbiol. Biotechnol. 102, 5033-5043. doi: 10.1007/ s00253-018-9035-0

Zhan, H., Huang, Y., Lin, Z., Bhatt, P., and Chen, S. (2020). New insights into the microbial degradation and catalytic mechanism of synthetic pyrethroids. Environ. Res. 182:109138. doi: 10.1016/j.envres.2020.109138

Zhang, Y. H., Xu, D., Liu, J. Q., and Zhao, X. H. (2014). Enhanced degradation of five organophosphorus pesticides in skimmed milk by lactic acid bacteria and its potential relationship with phosphatase production. Food Chem. 164, 173-178. doi: 10.1016/j.foodchem.2014.05.059

Zhang, Y., Zhang, W., Li, J., Pang, S., Mishra, S., Bhatt, P., et al. (2021). Emerging technologies for degradation of dichlorvos: a review. Int. J. Environ. Res. Public Health. 18:5789. doi: 10.3390/ijerph18115789

Zhao, M., Gu, H., Zhang, C. J., Jeong, I. H., Kim, J. H., and Zhu, Y. Z. (2020). Metabolism of insecticide diazinon by Cunninghamella elegans ATCC36112. RSC Adv. 10, 19659-19668. doi: 10.1039/D0RA02253E

Conflict of Interest: The authors declare that the research was conducted in the absence of any commercial or financial relationships that could be construed as a potential conflict of interest.

Publisher's Note: All claims expressed in this article are solely those of the authors and do not necessarily represent those of their affiliated organizations, or those of the publisher, the editors and the reviewers. Any product that may be evaluated in this article, or claim that may be made by its manufacturer, is not guaranteed or endorsed by the publisher.

Copyright (C) $2021 \mathrm{Wu}, \mathrm{Li}$, Zhou, Lin, Pang, Bhatt, Mishra and Chen. This is an open-access article distributed under the terms of the Creative Commons Attribution License (CC BY). The use, distribution or reproduction in other forums is permitted, provided the original author(s) and the copyright owner(s) are credited and that the original publication in this journal is cited, in accordance with accepted academic practice. No use, distribution or reproduction is permitted which does not comply with these terms. 